\title{
Development of PD-1 and PD-L1 inhibitors as a form of cancer immunotherapy: a comprehensive review of registration trials and future considerations
}

\author{
Jun Gong ${ }^{1}$, Alexander Chehrazi-Raffle ${ }^{2}$, Srikanth Reddi ${ }^{2}$ and Ravi Salgia ${ }^{3^{*}}$ (D)
}

\begin{abstract}
Early preclinical evidence provided the rationale for programmed cell death 1 (PD-1) and programmed death ligand 1 (PD-L1) blockade as a potential form of cancer immunotherapy given that activation of the PD-1/PD-L1 axis putatively served as a mechanism for tumor evasion of host tumor antigen-specific T-cell immunity. Early-phase studies investigating several humanized monoclonal IgG4 antibodies targeting PD-1 and PD-L1 in advanced solid tumors paved way for the development of the first PD-1 inhibitors, nivolumab and pembrolizumab, approved by the Food and Drug Administration (FDA) in 2014. The number of FDA-approved agents of this class is rapidly enlarging with indications for treatment spanning across a spectrum of malignancies. The purpose of this review is to highlight the clinical development of PD-1 and PD-L1 inhibitors in cancer therapy to date. In particular, we focus on detailing the registration trials that have led to FDA-approved indications of anti-PD-1 and anti-PD-L1 therapies in cancer. As the number of PD-1/PD-L1 inhibitors continues to grow, predictive biomarkers, mechanisms of resistance, hyperprogressors, treatment duration and treatment beyond progression, immune-related toxicities, and clinical trial design are key concepts in need of further consideration to optimize the anticancer potential of this class of immunotherapy.
\end{abstract}

Keywords: PD-1 inhibitor, PD-L1 inhibitor, Clinical trials, Biomarkers, Immune checkpoint, Hyperprogressors, Treatment beyond progression, Microbiome, Immune-related toxicity

\section{Background}

The programmed cell death protein 1 receptor (PD-1) receptor was first described in the early 1990s given its expression during induction of apoptosis in a T-cell hybridoma [1, 2]. Since its initial discovery several groups have identified that engagement of PD-1 through its ligand, programmed death ligand 1 (PD-L1), negatively regulates $\mathrm{T}$-cell-mediated immune responses [3-6]. Early preclinical evidence suggested that activation of PD-1/PD-L1 signaling could serve as a mechanism for tumors to evade an antigen-specific T-cell immunologic response [6-8]. Consequently, the

\footnotetext{
* Correspondence: rsalgia@coh.org

${ }^{3}$ Medical Oncology and Experimental Therapeutics, City of Hope

Comprehensive Cancer Center, Building 51, Room 101, 1500 E Duarte St,

Duarte, CA 91010, USA

Full list of author information is available at the end of the article
}

hypothesis was developed that PD-1/PD-L1 blockade may be an effective cancer immunotherapy (Fig. 1).

Initial phase I studies investigating several humanized monoclonal IgG4 antibodies targeting PD-1 and PD-L1 in advanced solid tumors were soon conducted and paved way for the development of the first PD-1 inhibitors, nivolumab and pembrolizumab, approved by the Food and Drug Administration (FDA) [9-11]. Immune checkpoint inhibitors targeting the PD-1/PDL1 axis are now approved in the treatment of several malignancies ranging from classical Hodgkin lymphoma to head and neck squamous cell carcinoma (HNSCC) [12].

Since the approval of pembrolizumab for the treatment of advanced melanoma in September 2014, the clinical development of PD-1 and PD-L1 inhibitors as anticancer agents has broadened (Table 1). Presently, the 


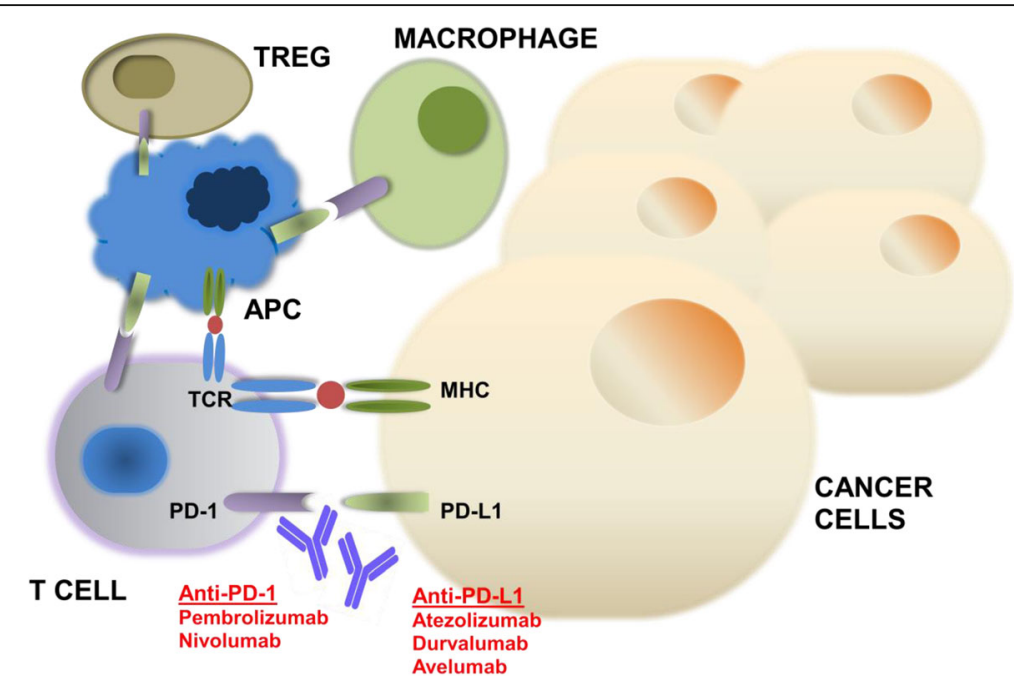

Fig. 1 Mechanism of action of PD-1 and PD-L1 inhibitors. The programmed cell death 1 (PD-1) receptor is expressed on activated T cells, B cells, macrophages, regulatory T cells (Tregs), and natural killer (NK) cells. Binding of PD-1 to its B7 family of ligands, programmed death ligand 1 (PD$\mathrm{L} 1$ or $\mathrm{B} 7-\mathrm{H} 1$ ) or PD-L2 (B7-DC) results in suppression of proliferation and immune response of T cells. Activation of PD-1/PD-L1 signaling serves as a principal mechanism by which tumors evade antigen-specific T-cell immunologic responses. Antibody blockade of PD-1 or PD-L1 reverses this process and enhances antitumor immune activity. TCR, T-cell receptor; MHC, major histocompatibility complex; APC, antigen-presenting cell

FDA has approved PD-1/PD-L1 inhibitors for the treatment of nine cancer types (Fig. 2). The purpose of this review is to highlight the clinical development of PD-1 and PD-L1 inhibitors in cancer therapy to date. In particular, we focus on detailing the registration trials that have led to FDA-approved indications of anti-PD-1 and anti-PD-L1 therapies in cancer and discuss future considerations important to optimizing their antitumor efficacy.

A literature search was conducted in MEDLINE using the following key words: "programmed death 1," programmed death-ligand 1," "PD-1," "PD-L1," "immune checkpoint inhibitor" and limited to published studies of English language up to October 1, 2017. Studies were further restricted to registration trials leading to FDAapproved indications in cancer therapy. An additional manual search was performed to include preliminary results from abstracts of potential relevance.

\section{Melanoma}

\section{Pembrolizumab}

On September 4, 2014, pembrolizumab (humanized monoclonal IgG4 antibody) became the first PD-1 inhibitor to receive approval for patients with advanced or

Table 1 Overview of PD-1/PD-L1 inhibitors, mechanisms of action, trial designations and approved companion diagnostics

\begin{tabular}{|c|c|c|c|}
\hline Agent & Mechanism of action & Trial name(s) & FDA-approved PD-L1 companion diagnostic \\
\hline Pembrolizumab & PD-1 inhibitor & KEYNOTE & $\begin{array}{l}\text { Primary antibody: 22C3 (Dako) } \\
\text { IHC scoring: Tumor cell membrane } \\
\text { Therapeutic developer: Merck }\end{array}$ \\
\hline Nivolumab & PD-1 inhibitor & CheckMate & $\begin{array}{l}\text { Primary antibody: } 28-8 \text { (Dako) } \\
\text { IHC scoring: Tumor cell membrane } \\
\text { Therapeutic developer: BMS }\end{array}$ \\
\hline Atezolizumab & PD-L1 inhibitor & IMVigor (UC), POPLAR (NSCLC), OAK (NSCLC) & $\begin{array}{l}\text { Primary antibody: SP142 (Ventana) } \\
\text { IHC scoring: Tumor cell membrane, } \\
\text { infiltrating immune cells } \\
\text { Therapeutic developer: Genentech }\end{array}$ \\
\hline Durvalumab & PD-L1 inhibitor & Study 1108 & $\begin{array}{l}\text { Primary antibody: SP263 (Ventana) } \\
\text { IHC scoring: Tumor cell membrane } \\
\text { Therapeutic developer: AstraZeneca }\end{array}$ \\
\hline Avelumab & PD-L1 inhibitor & JAVELIN & $\begin{array}{l}\text { Primary antibody: } 73-10\left(\text { Dako) }{ }^{a}\right. \\
\text { IHC scoring: Tumor cell membrane } \\
\text { Therapeutic developer: Merck, Pfizer }\end{array}$ \\
\hline
\end{tabular}

PD-1 programmed cell death 1, PD-L1 programmed death ligand 1, FDA Food and Drug Administration, IHC immunohistochemistry, BMS Bristol-Myers Squibb, UC urothelial carcinoma, NSCLC non-small cell lung cancer

${ }^{\text {a }}$ For research use only 


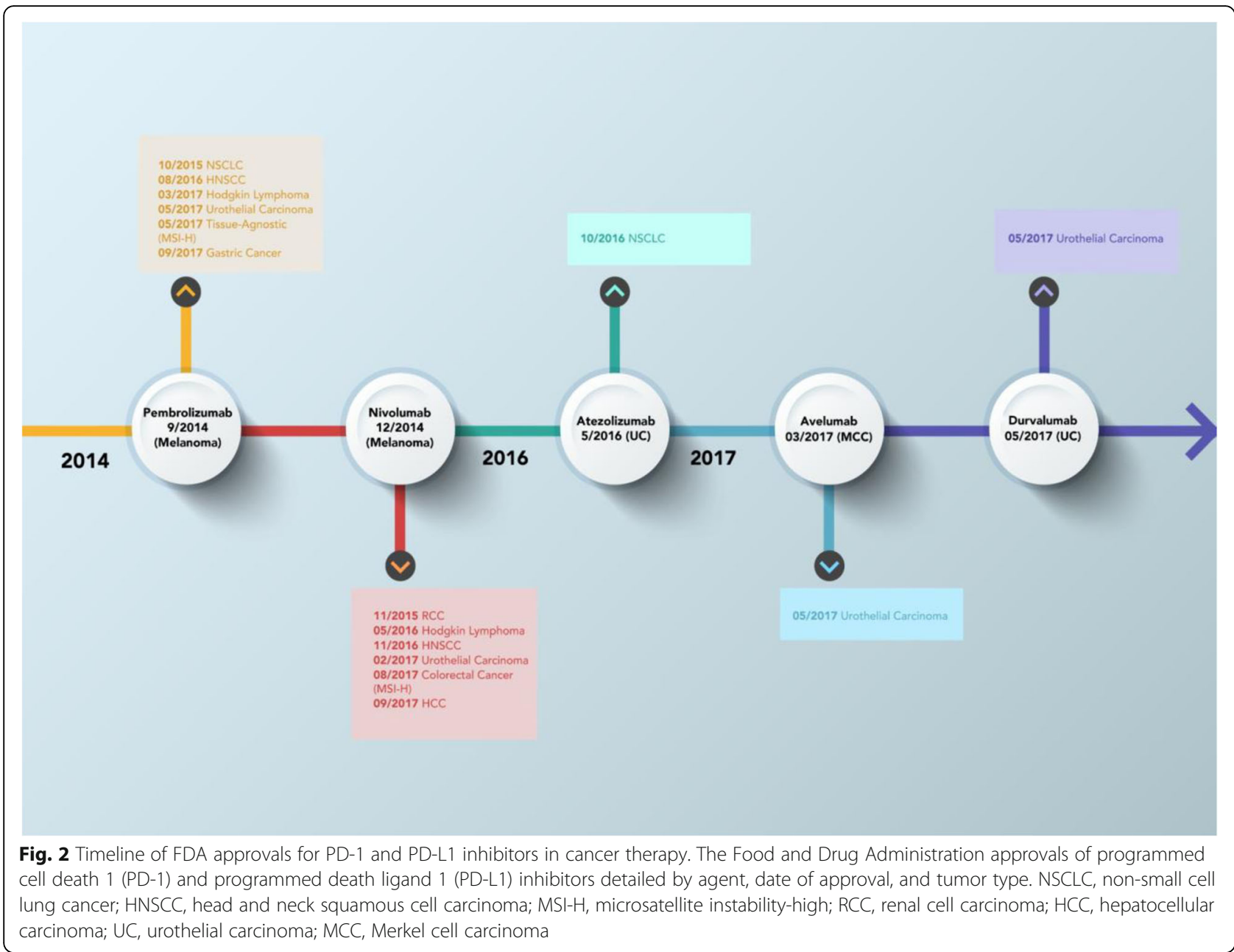

unresectable melanoma based on the findings from the KEYNOTE-001 study [13, 14]. In this phase I multicenter, international, open-label, randomized expansion of the KEYNOTE-001 cohort, 173 patients with advanced or unresectable melanoma who had previously failed treatment with ipilimumab and a BRAF inhibitor (if $B R A F^{V 600}$-mutated) were treated with pembrolizumab [14]. Patients were randomly assigned to treatment with pembrolizumab intravenous (IV) at $2 \mathrm{mg} / \mathrm{kg}$ every 3 weeks or $10 \mathrm{mg} / \mathrm{kg}$ every 3 weeks. The primary study endpoint was overall response rate (ORR) per RECIST 1.1. The ORR was $26 \%$ in both the pembrolizumab $2 \mathrm{mg} / \mathrm{kg}$ and $10 \mathrm{mg} / \mathrm{kg}$ groups (Table 2). Grade 3-4 drug-related adverse events (AEs) occurred in $15 \%$ of the pembrolizumab $2 \mathrm{mg} / \mathrm{kg}$ group (most common fatigue $6 \%$ ) and $8 \%$ of the pembrolizumab $10 \mathrm{mg} / \mathrm{kg}$ group (1 each of diarrhea, rash, dyspnea, hypoxia, maculopapular rash, pancreatitis, and musculoskeletal pain) [14]. In an update of KEYNOTE-001, findings after a median follow-up duration of 18 months for all patients were published [15]. Progression-free survival (PFS) at 6 months was 45\%, median overall survival (OS) was 25.9 months, and ORR
$34 \%$ in ipilimumab-treated and $45 \%$ in ipilimumab-naïve patients. Pembrolizumab was well tolerated as $14 \%$ of all patients experienced grade $\geq 3$ AEs.

On December 18, 2015, pembrolizumab received an expanded first-line indication to include previouslyuntreated advanced melanoma regardless of $B R A F$ mutation status following the results of the KEYNOTE-006 trial [16]. In this international, randomized, open-label phase 3 study, pembrolizumab $10 \mathrm{mg} / \mathrm{kg}$ every 2 weeks or every 3 weeks vs. ipilimumab $3 \mathrm{mg} / \mathrm{kg}$ every 3 weeks was evaluated in patients with advanced, unresectable stage III or IV melanoma who had received $\leq 1$ previous systemic therapy for advanced disease. Primary endpoints were PFS and OS and 6-month PFS for patients who received pembrolizumab every 2 weeks and every 3 weeks was $47.3 \%$ and $46.4 \%$, respectively, compared to $26.5 \%$ for those who received ipilimumab (hazard ratio (HR) for disease progression 0.58 for both pembrolizumab regimens vs. ipilimumab, 95\% confidence interval (CI) $0.46-0.72$ and 0.47-0.72, respectively, $p<0.001$ ). One-year OS and ORR rates were significantly improved in patients receiving either doses of pembrolizumab 
Table 2 Registration trials leading to the FDA approval of PD-1/PD-L1 inhibitors in melanoma

\begin{tabular}{|c|c|c|c|c|}
\hline Study/Agent & Tumor $(n)$ & Line of therapy & Experimental arm & Control arm \\
\hline $\begin{array}{l}\text { KEYNOTE-001 } \\
\text { (phase I)/ } \\
\text { pembrolizumab }\end{array}$ & $\begin{array}{l}\text { Advanced } \\
\text { melanoma } \\
(n=173)\end{array}$ & $\begin{array}{l}\text { Previously treated } \\
\text { with ipilimumab } \\
\text { and/or BRAF inhibitor }\end{array}$ & $\begin{array}{l}\text { Pembrolizumab } 2 \mathrm{mg} / \mathrm{kg} \\
\text { or } 10 \mathrm{mg} / \mathrm{kg} \text { every } \\
3 \text { weeks }\end{array}$ & \\
\hline $\begin{array}{l}\text { KEYNOTE-006 } \\
\text { (phase III)/ } \\
\text { pembrolizumab }\end{array}$ & $\begin{array}{l}\text { Advanced } \\
\text { melanoma } \\
(n=834)\end{array}$ & $\begin{array}{l}\text { First-line (regardless } \\
\text { of BRAF mutations } \\
\text { status) }\end{array}$ & $\begin{array}{l}\text { Pembrolizumab } 10 \text { mg/kg } \\
\text { every } 2 \text { weeks OR every } \\
3 \text { weeks }\end{array}$ & $\begin{array}{l}\text { Ipilimumab } 3 \mathrm{mg} / \mathrm{kg} \\
\text { every } 3 \text { weeks X4 } \\
\text { cycles }\end{array}$ \\
\hline
\end{tabular}

$\begin{array}{lc}\text { Primary endpoint }^{\text {a }} & \text { Ref } \\ \text { ORR 26\% (both doses; } & 14 \\ \text { difference 0\%, 95\% } & \\ \text { Cl 14-13, } p=0.96 \text { ) } & \\ \text { PFS (6-month) } 47.3 \% \text { vs. 46.4\% } & 16\end{array}$

vs. $26.5 \%$ (HR 0.58 for both pembrolizumab regimens vs. ipilimumab $95 \% \mathrm{Cl}$ 0.46-0.72 and $0.47-0.72$, respectively, $p<0.001)$

OS (1-year) $74.1 \%$ vs. $68.4 \%$ vs. $58.2 \%$ (HR pembrolizumab every 2 weeks $0.63,95 \% \mathrm{Cl}$ $0.47-0.83, p=0.0005 ; \mathrm{HR}$ pembrolizumab every 3 weeks $0.69,95 \%$ Cl 0.52-0.90, $p=0.0036)$

\begin{tabular}{|c|c|c|c|c|c|}
\hline $\begin{array}{l}\text { KEYNOTE-002 } \\
\text { (phase II)/ } \\
\text { pembrolizumab }\end{array}$ & $\begin{array}{l}\text { Advanced } \\
\text { melanoma } \\
(n=540)\end{array}$ & $\begin{array}{l}\text { Refractory to } \\
\text { ipilimumab and/or } \\
\text { BRAF inhibitor }\end{array}$ & $\begin{array}{l}\text { Pembrolizumab } 2 \text { mg/kg } \\
\text { every } 3 \text { weeks OR } 10 \\
\text { mg/kg every } 3 \text { weeks }\end{array}$ & $\begin{array}{l}\text { ICC (paclitaxel+ } \\
\text { carboplatin, paclitaxel, } \\
\text { carboplatin, dacarbazine, } \\
\text { or temozolomide) }\end{array}$ & $\begin{array}{l}\text { PFS } 2 \mathrm{mg} / \mathrm{kg}(\mathrm{HR} 0.5795 \% \mathrm{Cl} \\
0.45-0.73, \mathrm{p}<0.001) \text { and } \\
10 \mathrm{mg} / \mathrm{kg}(\mathrm{HR} 0.50,95 \% \mathrm{Cl} \\
0.39-0.64, p<0.001) \text { compared } \\
\text { to ipilimumab } \\
\text { No superiority in OS at } \\
\text { this interim analysis }\end{array}$ \\
\hline $\begin{array}{l}\text { CheckMate } 037 \\
\text { (phase III)/ } \\
\text { nivolumab }\end{array}$ & $\begin{array}{l}\text { Stage IIIC or } \\
\text { IV melanoma } \\
(n=405)\end{array}$ & Second-line & $\begin{array}{l}\text { Nivolumab } 3 \mathrm{mg} / \mathrm{kg} \\
\text { every } 2 \text { weeks }\end{array}$ & $\begin{array}{l}\text { Dacarbazine } 1000 \mathrm{mg} / \\
\mathrm{m} 2 \text { every } 3 \text { weeks } \\
\text { OR carboplatin } \\
\text { AUC } 6+\text { paclitaxel } \\
175 \mathrm{mg} / \mathrm{m}^{2} \text { every } \\
3 \text { weeks }\end{array}$ & $\begin{array}{l}\text { ORR } 31.7 \% \text { (95\% Cl 23.5-40.8) } \\
\text { vs. } 10.6 \% \text { (95\% 3.5-23.1) }\end{array}$ \\
\hline $\begin{array}{l}\text { CheckMate } 069 \\
\text { phase III)/ } \\
\text { nivolumab/ipilimumab }\end{array}$ & $\begin{array}{l}B R A F^{V 600}-\mathrm{WT} \\
\text { unresectable or } \\
\text { metastatic } \\
\text { melanoma } \\
(n=142)\end{array}$ & First-line & $\begin{array}{l}\text { Nivolumab } 1 \mathrm{mg} / \mathrm{kg}+ \\
\text { ipilimumab } 3 \mathrm{mg} / \mathrm{kg} \text { every } \\
3 \text { weeks } X 4 \text { cycles then } \\
\text { nivolumab alone every } \\
2 \text { weeks }\end{array}$ & $\begin{array}{l}\text { Ipilimumab } 3 \mathrm{mg} / \mathrm{kg} \text { every } \\
3 \text { weeks }\end{array}$ & ORR $61 \%$ vs. $11 \%(p<0.001)$ \\
\hline $\begin{array}{l}\text { CheckMate } 067 \\
\text { phase III)/ } \\
\text { nivolumab/ipilimumab }\end{array}$ & $\begin{array}{l}\text { Unresectable or } \\
\text { metastatic } \\
\text { melanoma } \\
(n=945)\end{array}$ & First-line & $\begin{array}{l}\text { Arm 1: Nivolumab } \\
3 \mathrm{mg} / \mathrm{kg} \text { every } 2 \text { weeks } \\
\text { Arm 2: nivolumab } \\
1 \mathrm{mg} / \mathrm{kg} \text { and ipilimumab } \\
3 \mathrm{mg} / \mathrm{kg} \text { every } 3 \text { weeks } \\
\text { for } 4 \text { doses followed } \\
\text { by nivolumab } 3 \mathrm{mg} / \mathrm{kg} \\
\text { of every } 2 \text { weeks }\end{array}$ & $\begin{array}{l}\text { Ipilimumab } 3 \mathrm{mg} / \mathrm{kg} \text { every } \\
3 \text { weeks }\end{array}$ & $\begin{array}{l}\text { PFS } 6.9 \text { mos (HR compared to } \\
\text { ipilimumab } 0.57,99.5 \% \mathrm{Cl} \\
0.43-0.76, \mathrm{p}<0.001 \text { vs. } 11.5 \mathrm{mo} \\
\text { (HR } 0.42,99.5 \% \mathrm{Cl} 0.31-0.57 \text {, } \\
\text { p< } 0.001 \text { compared to } \\
\text { ipilimumab) vs. } 2.9 \text { mos }\end{array}$ \\
\hline
\end{tabular}

${ }^{a}$ Order of results refers to the experimental arm and control arm, respectively. In trials with more than one experimental arm, the endpoints are in the same order as documented in the experimental arm column FDA Food and Drug Administration, $P D-1$ programmed cell death 1, $P D-L 1$ programmed death ligand 1, ORR overall response rate, $C l$ confidence interval, PFS progression-free survival, HR hazard ratio, OS overall survival, ICC investigator-choice chemotherapy, AUC area under curve, WT wild-type

compared to ipilimumab as well (Table 2). The most common grade 3-5 AEs of special interest were colitis (1.4\%, pembrolizumab every 2 weeks), colitis $(2.5 \%)$ and hepatitis ( $1.8 \%$, pembrolizumab every 3 weeks), and colitis (7.0\%, ipilimumab) [16].

Furthermore, the FDA approved a labeling update for pembrolizumab in ipilimumab-refractory melanoma based on findings from KEYNOTE-002 [17]. This study compared pembrolizumab and investigator-choice chemotherapy (ICC) for the treatment of unresectable stage III or stage IV ipilimumab and/or BRAF inhibitor-refractory melanoma. Patients $(n=540)$ were randomized to receive pembrolizumab $2 \mathrm{mg} / \mathrm{kg}$ every 3 weeks, pembrolizumab $10 \mathrm{mg} / \mathrm{kg}$ every 3 weeks, or ICC (paclitaxel plus carboplatin, paclitaxel, carboplatin, dacarbazine, or temozolomide). There was no statistically significant difference in OS between both pembrolizumab arms and chemotherapy at interim analysis. Doses of pembrolizu$\mathrm{mab} 2 \mathrm{mg} / \mathrm{kg}$ (HR 0.57, 95\% CI 0.45-0.73, $p<0.001$ ) and $10 \mathrm{mg} / \mathrm{kg}$ (HR 0.50, 95\% CI 0.39-0.64, p < 0.001) showed superior median PFS when compared to chemotherapy. Response rates were $21 \%$ in the pembrolizumab $2 \mathrm{mg} / \mathrm{kg}$ group and $25 \%$ in the $10 \mathrm{mg} / \mathrm{kg}$ group compared to $4 \%$ in the chemotherapy arm $(p<0.0001)$. Incidence of grade $3-$ 4 treatment-related AEs was higher in those given chemotherapy (26\%) than in those given pembrolizumab $2 \mathrm{mg} / \mathrm{kg}$ group (11\%) and pembrolizumab $2 \mathrm{mg} / \mathrm{kg}$ group (14\%) [17]. 


\section{Nivolumab}

On December 22, 2014, nivolumab was first approved as second-line treatment of unresectable or metastatic melanoma based on the CheckMate 037 trial [18]. This randomized controlled, open-label, international phase III study randomized 272 patients with unresectable stage IIIC or IV melanoma progressing after anti-CTLA-4 treatment or after anti-CTLA-4 treatment and a BRAF inhibitor for $B R A F^{V 600}$-mutated tumors to IV nivolumab $3 \mathrm{mg} / \mathrm{kg}$ every 2 weeks and 133 to ICC (Table 2). Positive PD-L1 expression was defined as $\geq 5 \%$ of tumor cells exhibiting PD-L1 staining (IHC 28-8 antibody) of any intensity in a section containing $\geq 100$ evaluable cells. The ORR was $31.7 \%$ in the nivolumab group and $10.6 \%$ in the chemotherapy group (Table 2). In patients with PDL1 positivity, ORR was $43.6 \%$ compared to $9.1 \%$ of the chemotherapy group. Grade $\geq 3$ nivolumab-related AEs were seen in $9 \%$ of patients and included elevated lipase, elevated alanine aminotransferase (ALT), fatigue, and anemia. Grade $\geq 3$ AEs occurred in $32 \%$ of chemotherapy patients, the most common of which were neutropenia, anemia, and thrombocytopenia.

The combination of nivolumab and ipilimumab was later approved as first-line treatment for $B R A F^{V 600}$-wildtype unresectable or metastatic melanoma on October 1 , 2015 based on results from CheckMate 069 [19]. This randomized, double-blinded phase III trial, compared nivolumab $1 \mathrm{mg} / \mathrm{kg}$ in combination with ipilimumab $3 \mathrm{mg} / \mathrm{kg}$ (every 3 weeks X4 cycles then nivolumab alone every 2 weeks) against ipilimumab $3 \mathrm{mg} / \mathrm{kg}$ monotherapy (every 3 weeks) as first-line treatment in 142 patients with advanced melanoma. Objective response occurred in $61 \%$ of patients with $B R A F^{V 600}$-wild-type tumors in the combination group compared with $11 \%$ of patients in the monotherapy group. Of note, overall response was independent of PD-L1 status in both the combination group ( $58 \%$ for PD-L1-positive $(\geq 5 \%)$ tumors vs. 55\% for PD-L1-negative tumors) and the monotherapy group (18\% for PD-L1- positive tumors and $4 \%$ for PD-L1 negative tumors). In patients with $B R A F^{V 600}$ mutated tumors, the ORR was $52 \%$ in the combination group compared with $10 \%$ in the monotherapy group. Grade $\geq 3$ AEs occurred more frequently in the combination group (54\%) than in the monotherapy group (24\%), the most common of which were colitis, diarrhea, and elevated ALT. Ipilimumab monotherapy-related grade $\geq 3$ AEs were seen in $24 \%$ of patients, the most common of which were diarrhea and colitis.

On January 23, 2016, nivolumab and ipilimumab combination therapy received an expanded approval for unresectable or metastatic melanoma irrespective of $B R A F^{V 600}$ mutation status based on results of the CheckMate 067 trial [20]. In this phase III trial, patients with untreated, unresectable or metastatic melanoma were randomized to receive nivolumab $3 \mathrm{mg} / \mathrm{kg}$ every 2 weeks, nivolumab $1 \mathrm{mg} / \mathrm{kg}$ and ipilimumab $3 \mathrm{mg} / \mathrm{kg}$ every 3 weeks for 4 doses followed by nivolumab $3 \mathrm{mg} /$ $\mathrm{kg}$ every 2 weeks, or ipilimumab $3 \mathrm{mg} / \mathrm{kg}$. Median PFS was 6.9 months in the nivolumab group, 11.5 months in the combination group, and 2.9 months in the ipilimumab group (Table 2). Longer OS was shown with nivolumab and combination therapy compared with ipilimumab alone across all subgroups (PD-L1 status, $B R A F^{V 600}$ status, and metastasis stage). The incidence of grade $\geq 3$ AEs was greater in the combination group (55\%) than in nivolumab or ipilimumab alone $(16.3 \%$ and $27.3 \%$, respectively). The most common grade $\geq 3$ AEs in the combination group were diarrhea, colitis, and increased ALT and aspartate aminotransferase (AST) whereas the most frequent grade $\geq 3$ AEs in the monotherapy arms were fatigue and diarrhea.

\section{Non-small cell lung cancer Pembrolizumab}

On October 2, 2015, pembrolizumab was approved for treatment of previously-treated advanced or metastatic PD-L1-positive non-small cell lung cancer (NSCLC) [21]. As part of the KEYNOTE-001 phase I study, 550 patients were treated with either pembrolizumab at a dose of $2 \mathrm{mg} / \mathrm{kg}$ every 2 weeks or $10 \mathrm{mg} / \mathrm{kg}$ every 2 or 3 weeks (Table 3 ). The primary endpoints were antitumor activity per RECIST 1.1 and safety. Of the 61 patients with tumors identified as strongly positive for PDL1 (PD-L1 $\geq 50 \%$ based on the companion diagnostic PD-L1 immunohistochemistry (IHC) 22C3 assay), the ORR for those receiving pembrolizumab $2 \mathrm{mg} / \mathrm{kg}$ was $28 \%$ (95\% CI $12.1-49.4 \%)$ as compared to $40 \%$ (95\% CI 22.4-61.2) and 41\% (95\% CI 24.7-59.3\%) in patients receiving pembrolizumab $10 \mathrm{mg} / \mathrm{kg}$ every 2 weeks and every 3 weeks, respectively. The most commonly occurring (>20\%) AEs included fatigue, decreased appetite, dyspnea, and cough. Immune-mediated AEs occurred in $13 \%$ of patients and included pneumonitis, colitis, hypophysitis, and thyroid disorders [21].

Updated long-term OS data for patients with previously-treated or treatment-naïve advanced or metastatic NSCLC were subsequently presented for the phase Ib KEYNOTE-001 study [22]. As compared to earlier studies that stratified tumor proportion score (TPS) cutoff of $1-50 \%$ and $\geq 50 \%$ PD-L1 staining of tumor cells, these investigators assessed a PD-L1 staining cutoff of $\geq 1 \%$ on tumor cells. Patients received either pembrolizumab $2 \mathrm{mg} / \mathrm{kg}$ every 3 weeks or $10 \mathrm{mg} / \mathrm{kg}$ every 2 or 3 weeks. Using a PD-L1 TPS cutoff of $\geq 1 \%$, median OS was 22.1 months (95\% CI 17.1-27.2) for treatment-naive patients and 10.6 months (95\% CI 8.6-13.3) for previously-treated patients, supporting the efficacy of pembrolizuamb in patients with a PD-L1 
Table 3 Registration trials leading to the FDA approval of PD-1/PD-L1 inhibitors in lung cancer

\begin{tabular}{|c|c|c|c|c|c|c|}
\hline Study/Agent & Tumor (n) & Line of therapy & Experimental arm & Control arm & Primary endpoint & Ref \\
\hline $\begin{array}{l}\text { KEYNOTE-001 } \\
\text { (phase Ib)/ } \\
\text { pembrolizumab }\end{array}$ & $\begin{array}{l}\text { Advanced } \\
\text { NSCLC } \\
(n=550)\end{array}$ & $\begin{array}{l}\text { PD-L1 positive } \\
(\geq 1 \%) \\
\text { progressing after } \\
\text { platinum-based } \\
\text { therapy }\end{array}$ & $\begin{array}{l}\text { Pembrolizumab } 2 \mathrm{mg} / \mathrm{kg} \text { every } \\
3 \text { weeks OR } 10 \mathrm{mg} / \mathrm{kg} \text { every } \\
2 \text { or } 3 \text { weeks }\end{array}$ & & $\begin{array}{l}\text { ORR 28\% (95\% Cl } \\
12.1-49.4 \%) \text { vs. 40\% } \\
(95 \% \text { Cl 22.4-61.2) } \\
\text { vs. } 41 \%(95 \% \mathrm{Cl} \\
24.7-59.3 \%) \text { for } \\
\text { PD-L1 } \geq 50 \% \\
\text { OS } 22.1 \text { mo } \\
\text { (treatment-naïve, } \\
95 \% \text { Cl 17.1-27.2) } \\
\text { vs. } 10.6 \text { mo } \\
\text { (previously-treated, } \\
\text { 95\% Cl 8.6-13.3) } \\
\text { for PD-L1 } 1250 \%\end{array}$ & $\begin{array}{l}21 \\
22\end{array}$ \\
\hline $\begin{array}{l}\text { KEYNOTE-024 } \\
\text { (phase III)/ } \\
\text { pembrolizumab }\end{array}$ & $\begin{array}{l}\text { Metastatic } \\
\text { NSCLC with } \\
\geq 50 \% \text { PD-L1 } \\
\text { expression } \\
(n=305)\end{array}$ & First-line & $\begin{array}{l}\text { Pembrolizumab } 200 \text { mg every } \\
3 \text { weeks }\end{array}$ & $\begin{array}{l}\text { ICC (cisplatin/ } \\
\text { carboplatin + pemetrexed, } \\
\text { cisplatin/carboplatin + } \\
\text { gemcitabine, or } \\
\text { carboplatin + paclitaxel) }\end{array}$ & $\begin{array}{l}\text { PFS } 10.3 \text { mos vs. } 6.0 \\
\text { mos (HR 0.50, } 95 \% \\
C l 0.37-0.68 \\
p<0.001)\end{array}$ & 25 \\
\hline $\begin{array}{l}\text { KEYNOTE-021 } \\
\text { (phase II)/ } \\
\text { pembrolizumab }\end{array}$ & $\begin{array}{l}\text { Advanced } \\
\text { NSCLC } \\
(n=123)\end{array}$ & $\begin{array}{l}\text { First line (in } \\
\text { combination with } \\
\text { platinum-doublet } \\
\text { chemotherapy) }\end{array}$ & $\begin{array}{l}\text { Pembrolizumab } 200 \mathrm{mg}+ \\
\text { carboplatin AUC } 5 \mathrm{mg} / \mathrm{ml} / \mathrm{min}+ \\
\text { pemetrexed } 500 \mathrm{mg} / \mathrm{m}^{2} \text { every } \\
3 \text { weeks X4 cycles followed by } \\
\text { pembrolizumab ( } 24 \text { months } \\
\text { duration) and indefinite } \\
\text { maintenance pemetrexed }\end{array}$ & $\begin{array}{l}\text { Carboplatin + pemetrexed } \\
\text { X4 cycles followed by } \\
\text { indefinite maintenance } \\
\text { pemetrexed }\end{array}$ & $\begin{array}{l}\text { ORR } 55 \% \text { vs. } 29 \% \\
\text { (estimated } \\
\text { treatment difference } \\
\text { of } 26 \%, 95 \% \mathrm{Cl} \\
9-42 \%, p=0.0016 \text { ) }\end{array}$ & 26 \\
\hline $\begin{array}{l}\text { CheckMate } 017 \\
\text { (phase III)/ } \\
\text { nivolumab }\end{array}$ & $\begin{array}{l}\text { Metastatic } \\
\text { squamous } \\
\text { NSCLC } \\
(n=272)\end{array}$ & $\begin{array}{l}\text { Previously treated } \\
\text { with platinum-based } \\
\text { chemo }\end{array}$ & $\begin{array}{l}\text { Nivolumab } 3 \text { mg/kg every } \\
2 \text { weeks }\end{array}$ & $\begin{array}{l}\text { Docetaxel } 75 \mathrm{mg} / \mathrm{m}^{2} \\
\text { every } 2 \text { weeks }\end{array}$ & $\begin{array}{l}\text { OS } 9.2 \text { mo vs. } 6.0 \\
\text { mos (HR 0.59, } 95 \% \\
C l 0.44-0.79 \\
p<0.001)\end{array}$ & 27 \\
\hline $\begin{array}{l}\text { CheckMate } 057 \\
\text { (phase III)/ } \\
\text { nivolumab }\end{array}$ & $\begin{array}{l}\text { Metastatic } \\
\text { non-squamous } \\
\operatorname{NSCLC~}(n=582)\end{array}$ & $\begin{array}{l}\text { Previously treated } \\
\text { with platinum-based } \\
\text { chemo }\end{array}$ & $\begin{array}{l}\text { Nivolumab } 3 \mathrm{mg} / \mathrm{kg} \text { every } \\
2 \text { weeks }\end{array}$ & $\begin{array}{l}\text { Docetaxel } 75 \mathrm{mg} / \mathrm{m}^{2} \\
\text { every } 3 \text { weeks }\end{array}$ & $\begin{array}{l}\text { OS } 12.2 \text { mos vs. } 9.4 \\
\text { mos (HR } 0.73,96 \% \\
\text { Cl } 0.59-0.89 \\
p=0.002)\end{array}$ & 28 \\
\hline $\begin{array}{l}\text { POPLAR (phase II)/ } \\
\text { OAK (phase III)/ } \\
\text { atezolizumab }\end{array}$ & $\begin{array}{l}\text { NSCLC (POPLAR } \\
n=287, \text { OAK } \\
n=1225)\end{array}$ & Second-line & $\begin{array}{l}\text { Atezolizumab } 1200 \text { mg every } \\
3 \text { weeks }\end{array}$ & Docetaxel 75 mg/m² & $\begin{array}{l}\text { POPLAR: OS } 12.6 \text { mos } \\
\text { vs. } 9.7 \text { mos (HR 0.7, } \\
95 \% \text { Cl 0.53-0.99, } \\
p=0.04) \\
\text { OAK: OS } 13.8 \text { mos } \\
\text { vs. } 9.6 \text { mos (HR } 0.73 \text {, } \\
95 \% \text { Cl } 0.62-0.87 \\
p=0.0003 \text { ) }\end{array}$ & $\begin{array}{l}29, \\
30\end{array}$ \\
\hline
\end{tabular}

FDA Food and Drug Administration, PD-1 programmed cell death 1, PD-L1 programmed death ligand 1, NSCLC non-small cell lung cancer, ORR overall response rate, $\mathrm{Cl}$ confidence interval, OS overall survival, ICC investigator-choice chemotherapy, PFS progression-free survival, $H R$ hazard ratio, $A U C$ area under curve

TPS $\geq 1 \%$ [22]. KEYNOTE-001 investigators attempted to define a tumor PD-L1 expression level associated with an enhanced likelihood of benefit as well as validate the safety and antitumor activity of pembrolizumab in patients with advanced NSCLC and PD-L1 $\geq 50 \%$ expression [23]. Patients received pembrolizumab $2 \mathrm{mg} / \mathrm{kg}$ every 3 weeks or $10 \mathrm{mg} / \mathrm{kg}$ every 2 or 3 weeks and were randomized to either a training group or validation group. In the training group, the PD-L1 cutoff was selected by immune-related response criteria by investigator review; in the validation group, membranous PD-L1 expression $\geq 50 \%$ was selected as the cutoff. The ORR was $45.2 \%$ in the patients with PD-L1 $\geq 50 \%$, including $43.9 \%$ in previously-treated patients and $50.0 \%$ in untreated patients. These values exceeded the response rate in the training group of
$36.6 \%$. Toxicities of grade $\geq 3$ were reported in $47 / 495$ patients $(9.5 \%)$ and were most commonly dyspnea (3.8\%), pneumonitis (1.8\%), decreased appetite $(1 \%)$, and asthenia (1\%) [23].

Following KEYNOTE-001, KEYNOTE-010 was a phase II/III clinical trial that randomized 1034 patients to pembrolizumab ( 2 or $10 \mathrm{mg} / \mathrm{kg}$ every 3 weeks) vs. docetaxel $\left(75 \mathrm{mg} / \mathrm{m}^{2}\right)$ for PD-L1-positive NSCLC that progressed after platinum-based chemotherapy or a tyrosine kinase inhibitor (TKI) for those with an EGFR-sensitizing mutation or $A L K$ gene rearrangement [24]. For patients with PD-L1 expression $\geq 1 \%$, median OS for pembrolizumab $2 \mathrm{mg} / \mathrm{kg}$ (HR 0.71, 95\% CI 0.58-0.88, $p=0.0008$ ) and $10 \mathrm{mg} / \mathrm{kg}$ (HR 0.61, 95\% CI 0.49-0.75, $p<0.0001$ ) and median PFS for pembrolizumab $10 \mathrm{mg} / \mathrm{kg}$ (HR 0.79, 95\% CI $0.66-0.94, p=0.004)$ were significantly improved 
compared to docetaxel with a trend towards improved PFS with pembrolizumab $2 \mathrm{mg} / \mathrm{kg}$. Pembrolizumab at both doses was superior to docetaxel in OS and PFS in those with $\geq 50 \%$ PD-L1 expression. Grade $\geq 3$ treatmentrelated AEs occurred in 13\% of the pembrolizumab $2 \mathrm{mg} /$ $\mathrm{kg}$ group, $16 \%$ of the pembrolizumab $10 \mathrm{mg} / \mathrm{kg}$ group, and $35 \%$ of the docetaxel group. Deaths attributed to treatment occurred in 3 patients in the pembrolizumab $2 \mathrm{mg} / \mathrm{kg}$ group (2 of pneumonitis and 1 pneumonia), 3 patients in the pembrolizumab $10 \mathrm{mg} / \mathrm{kg}$ group (myocardial infarction, pneumonia, and pneumonitis), and 5 patients in the docetaxel group [24].

On October 24, 2016, pembrolizumab received approval as first-line treatment for metastatic NSCLC with $\geq 50 \%$ PD-L1 expression and without EGFR or ALK genomic tumor aberrations [25]. In the phase III KEYNOTE-024 trial, 305 patients were randomized to receive either pembrolizumab $200 \mathrm{mg}$ every 3 weeks or ICC (platinum-based) for 4-6 cycles. Median PFS was 10.3 months in the pembrolizumab group as compared to 6.0 months in the chemotherapy group (HR 0.50, 95\% CI $0.37-0.68, p<0.001)$. Grade $\geq 3$ treatment-related AEs occurred in $26.6 \%$ of the pembrolizumab group and $53.3 \%$ of the chemotherapy group [25].

On May 10, 2017, pembrolizumab received approval to be given in combination with pemetrexed and carboplatin as first-line treatment of metastatic NSCLC, irrespective of PD-L1 expression [26]. In the phase II KEYNOTE-021 open-label trial, 123 patients with stage IIIB or IV NSCLC who did not demonstrate targetable EGFR mutations or $A L K$ translocations received either pembrolizumab $200 \mathrm{mg}$ plus pemetrexed $500 \mathrm{mg} / \mathrm{m}^{2}$ and carboplatin area under the curve (AUC) $5 \mathrm{mg} / \mathrm{mL} /$ min every 3 weeks for 4 cycles follow by pembrolizumab $200 \mathrm{mg}$ for 24 months and indefinite pemetrexed maintenance therapy, or pemetrexed $500 \mathrm{mg} / \mathrm{m}^{2}$ and carboplatin AUC $5 \mathrm{mg} / \mathrm{mL} / \mathrm{min}$ followed by indefinite pemetrexed maintenance therapy alone. The primary endpoint ORR was 55\% (33/60 patients) in the pembrolizumab plus chemotherapy group compared to $29 \%$ (18/ 63 patients) in the chemotherapy alone group, equating to an estimated treatment difference of $26 \%$ (95\% CI 9$42 \%, p=0.0016)$. The most common all-grade treatment-related AEs in the pembrolizumab arm vs. chemotherapy alone arm were fatigue ( $64 \%$ vs. $40 \%)$, nausea ( $58 \%$ vs. $44 \%$ ), and anemia ( $32 \%$ vs. $53 \%$ ).

\section{Nivolumab}

Nivolumab was approved as treatment for metastatic squamous NSCLC on March 4, 2015 based on the CheckMate 017 trial [27]. In this phase III study, patients who progressed during or after 1 prior platinum-containing chemotherapy regimen were randomized to receive nivolumab $3 \mathrm{mg} / \mathrm{kg}$ every 2 weeks or docetaxel $75 \mathrm{mg} / \mathrm{m}^{2}$ every 3 weeks (Table 3 ). The primary endpoint was OS and a key secondary endpoint included efficacy based on tumor cell PD-L1 expression levels of $1 \%, 5 \%$ or $10 \%$. Median OS was 9.2 months in the nivolumab group versus 6.0 months in the docetaxel group, and OS at 1 year was $42 \%$ in the nivolumab group versus $24 \%$ in the docetaxel group. PD-L1 expression was not predictive across any of the efficacy endpoints. Fewer all-grade treatment-related AEs occurred with nivolumab (58\%) than with docetaxel (86\%). The most frequently reported AEs were fatigue, decreased appetite, and asthenia with nivolumab compared to neutropenia, fatigue, and alopecia in the docetaxel arm. Grade $\geq 3$ AEs were found in $7 \%$ of patients with nivolumab (including colitis and pneumonitis) compared 57\% with docetaxel (including hemotologic toxicity and infections).

The CheckMate 057 trial ushered in the FDAexpanded approval of nivolumab in metastatic nonsquamous NSCLC on October 9, 2015 [28]. This phase III trial enrolled 582 patients who had progressed during or after platinum-based doublet chemotherapy to receive nivolumab $3 \mathrm{mg} / \mathrm{kg}$ every 2 weeks or docetaxel $75 \mathrm{mg} /$ $\mathrm{m}^{2}$ every 3 weeks. The primary endpoint was OS, which was 12.2 months with nivolumab and 9.4 months with docetaxel (Table 3). Treatment-related AEs occurred more frequently with docetaxel $(20 \%)$ than nivolumab (7\%). Grade $\geq 3$ nivolumab-related AEs include fatigue, nausea, asthenia, and diarrhea; grade $\geq 3$ docetaxelrelated AEs included fatigue, anemia, and asthenia.

\section{Atezolizumab}

On October 18, 2016, atezolizumab (PD-L1 inhibitor) was approved for previously-treated metastatic NSCLC following the results of the POPLAR and OAK trials [29, 30]. POPLAR is an ongoing phase II trial that randomized 287 patients to receive atezolizumab $1200 \mathrm{mg}$ or docetaxel $75 \mathrm{mg} / \mathrm{m}^{2}$ with emphasis placed on PD-L1 expression of tumor cells and tumor-infiltrating immune cells [29]. The primary endpoint was OS and at a minimum follow-up of 13 months, atezolizumab had significantly improved OS compared with docetaxel (12.6 months vs. 9.7 months, $p=0.04$ ). Increasing OS improvement was seen in subgroups with greater tumor cell and immune cell PD-L1 expression. However, unlike OS, improved PFS and ORR was limited to only those patients with the highest levels of PD-L1 expression (tumor cell $\geq 50 \%$ or immune cell $\geq 10 \%$ ). The most common atezolizumab-related AEs were pneumonia and elevated AST levels.

Similarly, OAK is an ongoing phase III trial that randomized patients with previously-treated advanced NSCLC to atezolizumab $1200 \mathrm{mg}$ every 3 weeks or docetaxel $75 \mathrm{mg} / \mathrm{m}^{2}$ every 3 weeks [30]. Patients were 
stratified by PD-L1 expression, number of previous chemotherapy regimens, and histology (squamous vs. non-squamous). OS was improved regardless of PD-L1 expression (Table 3) though patients with the highest PD-L1 expression experienced the greatest benefit from atezolizumab with a median OS of 20.5 months compared with 8.9 months in the docetaxel group. Grade $\geq 3$ AEs were observed in $64 \%$ of patients in the atezolizumab cohort and included fatigue and anemia. Docetaxelrelated grade $\geq 3$ AEs were seen in $86 \%$ and were most frequently febrile neutropenia, neutropenia, anemia, and fatigue.

\section{Durvalumab}

Although not FDA approved, it is worthwhile to mention that the PD-L1 inhibitor durvalumab was recently granted FDA breakthrough designation in the adjuvant treatment of locally advanced, unresectable NSCLC based on the phase III PACIFIC trial [31]. The primary endpoint was PFS, and 713 patients who did not demonstrate PD after $\geq 2$ cycles of platinum-based chemotherapy concurrent with definitive RT were randomized to durvalumab $(10 \mathrm{mg} / \mathrm{kg})$ or placebo within 1-42 days after chemoradiotherapy every 2 weeks for up to 1 year. Durvalumab demonstrated superior PFS (median PFS 16.8 months, 95\% CI 13.0-18.1) over placebo (5.6 months, 95\% CI 4.6-7.8) in this setting (HR 0.52, $95 \%$ CI $0.42-0.65, p<0.001)$. Safety was similar between both treatment arms with $29.9 \%$ of durvalumab patients and $26.1 \%$ of placebo patients experiencing grade $3-4$ AEs. Improved outcomes were observed in the experimental arm irrespective of PD-L1 status or histology.

\section{Urothelial cancer Pembrolizumab}

On May 18, 2017, pembrolizumab received 2 FDA approvals: in patients with locally advanced or metastatic urothelial carcinoma (UC) who have disease progression after platinum-containing chemotherapy and in patients who are cisplatin-ineligible [32, 33]. In the phase III, international KEYNOTE-045 trial, 542 patients with advanced UC showing $\geq 10 \%$ PD-L1 expression who had previously failed platinum-based chemotherapy were randomized to receive pembrolizumab $200 \mathrm{mg}$ every 3 weeks or either paclitaxel, docetaxel, or vinflunine [33]. Median OS was significantly higher in the pembrolizumab group compared to chemotherapy though there was no significant difference in PFS (Table 4). Fewer grade $\geq 3$ AEs occurred with pembrolizumab compared to the chemotherapy arm (15.0\% vs. 49.4$)$. Median OS was also significantly improved with pembrolizumab compared to chemotherapy (HR $0.57,95 \%$ CI $0.37-0.88$, $p=0.005)$ in those with PD-L1 expression $\geq 10 \%$ but there was no difference in PFS between arms in this population. In the phase II, open-label KEYNOTE-052 trial, patients with locally advanced or metastatic urothelial carcinoma who were cisplatin-ineligible received first-line pembrolizumab $200 \mathrm{mg}$ every 3 weeks until progressive disease, unacceptable toxicity, or 24 months of treatment. The primary endpoint was ORR per RECIST 1.1. Of 370 enrolled patients, the ORR was $27 \%$ (95\% CI 22-32) in those who had enrolled for $\geq 4$ months. Grade $\geq 3$ AEs occurred in 52 patients (14\%) with 19 (5\%) discontinuing therapy due to AEs [32].

\section{Nivolumab}

The FDA approved nivolumab on February 2, 2017 for locally advanced or metastatic UC following the results from CheckMate 275 [34]. This phase II study enrolled 270 patients who had experienced progression or recurrence after $\geq 1$ platinum-based chemotherapy regimen to receive nivolumab $3 \mathrm{mg} / \mathrm{kg}$ every 2 weeks (Table 4). The primary endpoint was ORR in all treated patients stratified by PD-L1 expression ( $28.4 \%$ for $\geq 5 \%, 23.8 \%$ for $\geq 1 \%$, and $16.1 \%$ for $<1 \%$ ). At median follow up of 7 months, OS was 11.30 months in the $\mathrm{PD}-\mathrm{L} 1 \geq 1 \%$ subgroup and 5.95 months in the PD-L1 $<1 \%$ subgroup. Grade $3-4$ AEs related to nivolumab included diarrhea and fatigue.

\section{Atezolizumab}

On May 18, 2016, atezolizumab became the first PD-L1 inhibitor approved for locally advanced and metastatic UC based on results of IMVigor 210 [35]. This phase II trial enrolled 310 patients whose disease had progressed after receiving platinum-based chemotherapy to receive a fixed dose of atezolizumab $1200 \mathrm{mg}$ every 3 weeks (Table 4). PD-L1 status was subdivided by the percentage of PD-L1-positive immune cells in the tumor microenvironment (TME): $<1 \%, \geq 1 \%$ but $<5 \%$, and $\geq 5 \%$. The primary endpoint was ORR. In all patients, ORR was $15 \%$, a significant improvement compared to the historical response rate of $10 \%$. In addition, subgroup analysis showed a PD-L1-related response: PD-L1 $\geq 5 \%$ showed a $27 \%$ ORR, PD-L $1 \geq 1 \%$ showed $18 \%$ ORR, and PD $<1 \%$ showed $8 \%$ response. Sixteen percent of patients experienced grade 3-4 treatment-related AEs, the most common of which were fatigue, anemia, and hypertension. Notably a recent press release for the confirmatory IMVigor 211 trial reported a failure to meet the study's primary endpoint (see Discussion).

Accelerated approval of atezolizumab in the first-line treatment of cisplatin-ineligible patients with locally advanced and metastatic UC occurred based on a separate cohort of the IMVigor 210 trial [36]. This phase II, single-arm trial administered atezolizumab $1200 \mathrm{mg}$ every 3 weeks to 119 treatment-naïve metastatic UC 
Table 4 Registration trials leading to the FDA approval of PD-1/PD-L1 inhibitors in urothelial carcinoma and renal cell carcinoma

\begin{tabular}{|c|c|c|c|c|c|c|}
\hline Study/Agent & Tumor (n) & Line of therapy & $\begin{array}{l}\text { Experimental } \\
\text { arm }\end{array}$ & Control arm & Primary endpoint & $\operatorname{Re}$ \\
\hline $\begin{array}{l}\text { KEYNOTE-052 } \\
\text { (phase II)/ } \\
\text { pembrolizumab }\end{array}$ & $\begin{array}{l}\text { Urothelial carcinoma } \\
(n=370)\end{array}$ & $\begin{array}{l}\text { First-line cisplatin- } \\
\text { ineligible }\end{array}$ & $\begin{array}{l}\text { Pembrolizumab } \\
200 \text { mg every } \\
3 \text { weeks }\end{array}$ & & ORR 24\% (95\% Cl 20-29) & 32 \\
\hline $\begin{array}{l}\text { KEYNOTE-045 } \\
\text { (phase III)/ } \\
\text { pembrolizumab }\end{array}$ & $\begin{array}{l}\text { Urothelial carcinoma } \\
(n=542)\end{array}$ & $\begin{array}{l}\text { Refractory to platinum- } \\
\text { based chemotherapy }\end{array}$ & $\begin{array}{l}\text { Pembrolizumab } \\
200 \text { mg every } \\
3 \text { weeks }\end{array}$ & $\begin{array}{l}\text { Paclitaxel } 175 \mathrm{mg} / \mathrm{m}^{2} \\
\text { OR docetaxel } \\
75 \mathrm{mg} / \mathrm{m}^{2} \text { OR vinflunine } \\
320 \mathrm{mg} / \mathrm{m}^{2}\end{array}$ & $\begin{array}{l}\text { OS } 10.3 \text { mos vs. } 7.4 \text { mos } \\
\text { (HR } 0.73,95 \% \text { Cl } 0.59-0.91 \\
p=0.002) \\
\text { PFS HR } 0.98,95 \% \text { Cl 0.81-1.19, } \\
p=0.42\end{array}$ & 33 \\
\hline $\begin{array}{l}\text { CheckMate } 275 \\
\text { (phase II)/ } \\
\text { nivolumab }\end{array}$ & $\begin{array}{l}\text { Advanced urothelial } \\
\text { carcinoma }(n=270)\end{array}$ & $\begin{array}{l}\text { Previously treated } \\
\text { with platinum-based } \\
\text { chemotherapy }\end{array}$ & $\begin{array}{l}\text { Nivolumab } \\
3 \mathrm{mg} / \mathrm{kg} \text { every } \\
2 \text { weeks }\end{array}$ & & $\begin{array}{l}\text { ORR } 28.4 \% \text { ( } 95 \% \text { Cl } 18.9-39.5) \\
\text { for } 81 \text { patients with PD-L1 } \geq 5 \% \text {, } \\
23.8 \%(95 \% \text { Cl 16.5-32.3) for } \\
122 \text { PD-L1 } \geq 1 \% \text {, and } 16.1 \% \\
\text { (95\% CI } 10.5-23.1) \text { for } 143 \text { with } \\
\text { PD-L1 < } 1 \%\end{array}$ & 34 \\
\hline $\begin{array}{l}\text { IMVigor } 210 \text { (phase } \\
\text { II)/atezolizumab }\end{array}$ & $\begin{array}{l}\text { Urothelial carcinoma } \\
(n=315)\end{array}$ & $\begin{array}{l}\text { Previously treated with } \\
\text { platinum-based } \\
\text { chemotherapy }\end{array}$ & $\begin{array}{l}\text { Atezolizumab } \\
1200 \mathrm{mg} \text { every } \\
3 \text { weeks }\end{array}$ & & $\begin{array}{l}\text { ORR 27\% (95\% Cl 19-37, } \\
p<0.0001) \text { for PD-L1 } \geq 5 \% \\
18 \%(95 \% \mathrm{Cl} 13-24, p=0.0004) \\
\text { for PD-L1 } \geq 1 \%, 15 \%(95 \% \mathrm{Cl} \\
11-20, p=0.0058) \text { for all patients } \\
\text { compared to historical control }\end{array}$ & 35 \\
\hline $\begin{array}{l}\text { IMVigor } 210 \text { (phase } \\
\text { II)/atezolizumab }\end{array}$ & $\begin{array}{l}\text { Urothelial carcinoma } \\
(n=119)\end{array}$ & $\begin{array}{l}\text { First-line cisplatin- } \\
\text { ineligible }\end{array}$ & $\begin{array}{l}\text { Atezolizumab } \\
1200 \mathrm{mg} \text { every } \\
3 \text { weeks }\end{array}$ & & $\begin{array}{l}\text { ORR 23\% (95\% Cl 16-31) in } \\
\text { total population }\end{array}$ & 36 \\
\hline $\begin{array}{l}\text { Study } 1108 \text { (phase } \\
\text { II)/durvalumab }\end{array}$ & $\begin{array}{l}\text { Urothelial carcinoma } \\
(n=191)\end{array}$ & Second-line & $\begin{array}{l}\text { Durvalumab } \\
10 \mathrm{mg} / \mathrm{kg} \text { every } \\
2 \text { weeks }\end{array}$ & & $\begin{array}{l}\text { ORR } 17.8 \%(95 \% \mathrm{Cl} 12.7-24.0) \\
\text { in all patients, } 27.6 \%(95 \% \mathrm{Cl} \\
19.0-37.5) \text { for PD-L1 } \geq 25 \% \text {, and } \\
5.1 \% \text { (95\% Cl 1.4-12.5) for } \\
\text { PD-L1-negative }\end{array}$ & 38 \\
\hline $\begin{array}{l}\text { JAVELIN Solid } \\
\text { Tumor (phase I)/ } \\
\text { avelumab }\end{array}$ & $\begin{array}{l}\text { Urothelial carcinoma } \\
(n=249)\end{array}$ & Second-line & $\begin{array}{l}\text { Avelumab } \\
10 \mathrm{mg} / \mathrm{kg} \text { every } \\
2 \text { weeks }\end{array}$ & & $\begin{array}{l}\text { ORR } 17.4 \% \text { ( } 95 \% \mathrm{Cl} 11.9-24.1 \text {, } \\
\text { complete response in } 6.2 \% \text { ) for } \\
61 \text { post-platinum patients } \geq 6 \\
\text { months of follow-up }\end{array}$ & 40 \\
\hline $\begin{array}{l}\text { CheckMate } 025 \\
\text { (phase III)/ } \\
\text { nivolumab }\end{array}$ & $\begin{array}{l}\text { Advanced RCC } \\
(n=821)\end{array}$ & Second-line & $\begin{array}{l}\text { Nivolumab } \\
3 \mathrm{mg} / \mathrm{kg} \text { every } \\
2 \text { weeks }\end{array}$ & Everolimus 10 mg daily & $\begin{array}{l}\text { OS } 25.0 \text { mos vs. } 19.6 \text { mos (HR } \\
0.73,98.5 \% \mathrm{Cl} 0.57-0.93 \\
p=0.002)\end{array}$ & 41 \\
\hline
\end{tabular}

FDA Food and Drug Administration, $P D-1$ programmed cell death 1, $P D-L 1$ programmed death ligand 1, ORR overall response rate, $C l$ confidence interval, $O S$ overall survival, $H R$ hazard ratio, PFS progression-free survival, $R C C$ renal cell carcinoma

with stratification based on PD-L1 expression as in the earlier IMVigor 210 trial. The primary endpoint was independently confirmed ORR per RECIST v1.1. In the primary analysis, efficacy did not reach (PD-L1 $\geq 5 \%$ subgroup) the pre-specified ORR of $10 \%$ after a median follow-up of 8.5 months. After a 17.2 month median follow up duration, the ORR increased to $28 \%$ in the PD$\mathrm{L} 1 \geq 5 \%$ subgroup, $21 \%$ in the $\geq 1 \%$ PD-L1 but $<5 \%$ group, and $21 \%$ in the PD-L $1<1 \%$ group. Interestingly, median OS was 15.9 months in all patients, 12.3 months in PD-L1 $\geq 5 \%$ patients, and 19.1 months in PD-L1 $<5 \%$ patients. The most common grade 3-4 treatment-related AEs were fatigue and elevated AST and ALT.

\section{Durvalumab}

Durvalumab received FDA approval on May 1, 2017 for the treatment of platinum-refractory locally advanced or metastatic UC based on results from Study 1108 [37]. In this phase I/II dose-escalation and expansion study, 61 patients who had progressed on, been ineligible for, or refused prior therapies for advanced disease were enrolled to receive the PD-L1 inhibitor durvalumab $10 \mathrm{mg} / \mathrm{kg}$ of every 2 weeks. Patients were initially enrolled regardless of PD-L1 expression, but enrollment was later restricted to patients with $\geq 5 \%$ PD-L1 expression on tumor cells after preliminary data suggested PDL1 was expressed more commonly on immune cells than tumor cells. The primary endpoint was safety and of 42 treated patients, grade $\geq 3$ AEs occurred in 3 patients. Of note, the ORR was $31.0 \%$ in all 42 patients, $46.4 \%$ in the PD-L1-positive subgroup, and $0 \%$ in the PD-L1-negative subgroup.

In an update of Study 1108, results were presented regarding the efficacy and tolerability of durvalumab $10 \mathrm{mg} / \mathrm{kg}$ every 2 weeks up to 12 months [38]. High PDL1 expression was defined as $\geq 25 \%$ of tumor or immune cells (Ventana SP263 assay). The primary endpoint was ORR using RECIST 1.1 (Table 4). Of the 191 treated 
patients, ORR was $17.8 \%$ (95\% CI 12.7-24.0) in all patients, 27.6\% (95\% CI 19.0-37.5) for PD-L1 $\geq 25 \%$, and 5.1\% (95\% CI 1.4-12.5) for PD-L1-negative. Grade 3-4 AEs related to treatment were seen in only $6.8 \%$ of patients.

\section{Avelumab}

Avelumab (PD-L1 inhibitor) received accelerated approval for locally advanced or metastatic UC following the JAVELIN Solid Tumor study [39]. In this phase Ib study, 44 patients with metastatic or locally advanced solid tumors after platinum-based therapy were given escalating doses of avelumab $10 \mathrm{mg} / \mathrm{kg}$ every 2 weeks. The primary endpoint was safety and 1 dose-limiting toxicity was reported at dose level 4 in a patient with metastatic thymoma who developed autoimmune disorder and increased blood creatine phosphokinase (CPK). Grade 3-4 treatment-related AEs occurred in 3 patients (6.8\%) and included asthenia, AST elevation, elevated CPK, and decreased appetite.

In the phase Ib update to the JAVELIN Solid Tumor study (Table 4), dose-expansion occurred up to 249 patients with metastatic UC refractory to platinum-based therapy or ineligible for cisplatintherapy [40]. In 161 post-platinum patients with $\geq 6$ months of follow-up, responses were seen across PD-L1 expression levels tested $(\geq 5 \%$ and $<5 \%$ PD-L1 tumor cell-staining $(25.4 \%$ and $13.2 \%$, respectively). Immune-related AEs occurred in 34 pts. (13.7\%) with an incidence of grade $\geq 3$ events in $2.4 \%$.

\section{Renal cell carcinoma}

\section{Nivolumab}

On November 23, 2015, nivolumab became the first PD-1 inhibitor approved for use in treatment-refractory clearcell renal cell carcinoma (RCC) based on results from CheckMate 025 [41]. In this phase III study, 821 patients were randomized to receive nivolumab $3 \mathrm{mg} / \mathrm{kg}$ every 2 weeks or oral everolimus $10 \mathrm{mg}$ daily (Table 4). The primary endpoint was OS, which was 25.0 months with nivolumab and 19.6 months with everolimus. Of note, patients with $\geq 1 \%$ PD-L1 expression demonstrated median OS of 21.8 months with nivolumab and 18.8 months with everolimus. Similar results were seen in patients with $\geq 5 \%$ PDL1 expression, though interpretation is limited by the small sample size in this subgroup. The most frequent grade $\geq 3$ AEs were fatigue with nivolumab and anemia with everolimus (19\% and 37\%, respectively).

\section{Head and neck cancer Pembrolizumab}

On August 5, 2016, pembrolizumab received accelerated approval for recurrent or metastatic HNSCC with disease progression on or after platinum-containing chemotherapy [42]. The KEYNOTE-012 open-label, multicenter, phase Ib trial studied the efficacy and safety of pembrolizumab in patients with $\geq 1 \%$ of tumor cells that were PD-L1-positive. Sixty patients received pembrolizumab $10 \mathrm{mg} / \mathrm{kg}$ every 2 weeks for 24 months and the primary endpoints were safety and ORR per RECIST 1.1 (Table 5). The ORR was $18 \%$ (95\% CI 8-32\%) and 10 (16.7\%) experienced grade $\geq 3$ AEs with the most common being transaminitis, hyponatremia, and rash.

\section{Nivolumab}

On November 10, 2016, nivolumab became the first immunotherapy approved by the FDA for HNSCC based on results from CheckMate 141 [43]. This phase III trial randomized 361 patients with disease that recurred or progressed within 6 months of the last dose of platinum-containing chemotherapy to nivolumab $3 \mathrm{mg} /$ kg every 2 weeks or ICC (Table 5). The primary endpoint was OS, which was 7.5 months with nivolumab and 5.1 months with ICC. Estimated 6-month PFS rates were $19.7 \%$ (nivolumab) and $9.9 \%$ (ICC). Grade $\geq 3$ nivolumab-related AEs occurred in 13\% and included fatigue, anemia, asthenia, and stomatitis. Grade $\geq 3$ chemotherapy-related AEs were seen in 35\% and most commonly were anemia and neutropenia.

\section{Hodgkin lymphoma \\ Pembrolizumab}

On March 15, 2017, pembrolizumab received approval for a hematologic malignancy based on the findings from the KEYNOTE-087 trial (Table 5) [44]. Patients ( $n$ $=210$ ) with relapsed or refractory classical Hodgkin Lymphoma (cHL from 3 cohorts: 1.) after autologous stem cell transplantation (ASCT) and subsequent brentuximab vedotin (BV), 2.) after salvage chemotherapy and BV with chemoresistant disease, and 3.) after ASCT but without BV after transplantation received pembrolizumab $200 \mathrm{mg}$ every 3 weeks for a maximum of 24 weeks. The ORR was $73.9 \%$ for cohort $1,64.2 \%$ for cohort 2 , and $70.0 \%$ for cohort 3 . The most common grade $\geq 3$ treatment-related $\mathrm{AE}$ was neutropenia (2.4\%).

\section{Nivolumab}

On May 17, 2016, nivolumab received the first approval for a PD-1 inhibitor in the treatment of a hematologic malignancy based on the findings from CheckMate 039 and CheckMate 205 (Table 5) [45, 46]. CheckMate 039 was a phase I study consisting of dose-escalation and expansion cohorts of patients with relapsed or refractory hematologic cancers treated with nivolumab $1 \mathrm{mg} / \mathrm{kg}$ with escalation to $3 \mathrm{mg} / \mathrm{kg}$, and patients in the expansion cohort received nivolumab $3 \mathrm{mg} / \mathrm{kg}$ at week 1 , week 4 , and every 2 weeks up to 2 years [45]. The primary endpoint was safety, and of the 23 patients with cHL enrolled, grade $\geq 3 \mathrm{AEs}$ were seen 
Table 5 Registration trials leading to the FDA approval of PD-1/PD-L1 inhibitors in head and neck cancer, classical Hodgkin lymphoma, colorectal cancer, gastroesophageal cancer, hepatocellular cancer, and other solid cancers

\begin{tabular}{|c|c|c|c|c|c|c|}
\hline Study/Agent & Tumor (n) & Line of therapy & $\begin{array}{l}\text { Experimental } \\
\text { arm }\end{array}$ & Control arm & Primary endpoint & Ref. \\
\hline $\begin{array}{l}\text { KEYNOTE-012 } \\
\text { (phase Ib)/ } \\
\text { pembrolizumab }\end{array}$ & $\operatorname{HNSCC}(n=60)$ & $\begin{array}{l}\mathrm{PD}-\mathrm{L} 1 \geq 1 \% \text { and } \\
\text { refractory to } \\
\text { platinum chemotherapy }\end{array}$ & $\begin{array}{l}\text { Pembrolizumab } \\
10 \mathrm{mg} / \mathrm{kg} \text { every } \\
2 \text { weeks }\end{array}$ & & $\begin{array}{l}\text { Safety } 45 \% \text { with serious AEs, } \\
17 \% \text { with grade } 3-4 \text { AEs (most } \\
\text { common transaminitis, } \\
\text { hyponatremia, and rash) } \\
\text { ORR } 18 \%(95 \% \text { Cl 8-32\%) }\end{array}$ & 42 \\
\hline $\begin{array}{l}\text { CheckMate } 141 \\
\text { (phase III)/ } \\
\text { nivolumab }\end{array}$ & $\operatorname{HNSCC}(n=361)$ & $\begin{array}{l}\text { Previously treated with } \\
\text { platinum-based } \\
\text { chemotherapy }\end{array}$ & $\begin{array}{l}\text { Nivolumab } \\
3 \mathrm{mg} / \mathrm{kg} \text { every } \\
2 \text { weeks }\end{array}$ & $\begin{array}{l}\text { ICC: either weekly } \\
\text { cetuximab } \\
250 \mathrm{mg} / \mathrm{m}^{2} \text { after a } \\
\text { loading dose of } \\
400 \mathrm{mg} / \mathrm{m}^{2} \text {, } \\
\text { weekly } \\
\text { methotrexate } 40- \\
60 \mathrm{mg} / \mathrm{m}^{2} \text {, or } \\
\text { weekly docetaxel } \\
30-40 \mathrm{mg} / \mathrm{m}^{2}\end{array}$ & $\begin{array}{l}\text { OS } 7.5 \text { mos vs. } 5.1 \text { mos (HR } \\
0.70,97.73 \% \text { Cl } 0.51-0.96 \\
p=0.01 \text { ) }\end{array}$ & 43 \\
\hline $\begin{array}{l}\text { KEYNOTE-087 } \\
\text { (phase II)/ } \\
\text { pembrolizumab }\end{array}$ & $\mathrm{CHL}(\mathrm{n}=210)$ & $\begin{array}{l}\text { Relapsed after } \geq 3 \text { lines } \\
\text { of therapy or refractory } \\
\mathrm{CHL}\end{array}$ & $\begin{array}{l}\text { Pembrolizumab } \\
200 \mathrm{mg} \text { every } \\
3 \text { weeks }\end{array}$ & & $\begin{array}{l}\text { ORR 69.0\% (95\% Cl 62.3- } \\
75.2 \%) \\
\text { CR 22.4\% (95\% Cl 16.9- 28.6\%) }\end{array}$ & 44 \\
\hline $\begin{array}{l}\text { CheckMate } 039 \\
\text { (phase I), } \\
\text { CheckMate } 205 \\
(\text { phase II)/nivolumab }\end{array}$ & $\mathrm{CHL}(n=80)$ & $\begin{array}{l}\text { Previously treated with } \\
\text { ASCT or brentuximab }\end{array}$ & $\begin{array}{l}\text { Nivolumab } \\
3 \mathrm{mg} / \mathrm{kg} \text { every } \\
2 \text { weeks }\end{array}$ & & ORR 66.3\% (95\% Cl 54.8-76.4) & $\begin{array}{l}45 \\
46\end{array}$ \\
\hline $\begin{array}{l}\text { Five phase I and II } \\
\text { trials (including } \\
\text { KEYNOTE-164 and } \\
\text { KEYNOTE-158)/ } \\
\text { pembrolizumab }\end{array}$ & $\begin{array}{l}\text { MSI-H or dMMR } \\
\text { unresectable or } \\
\text { metastatic solid } \\
\text { tumors ( } n=149 \\
\text { across five trials) }\end{array}$ & $\begin{array}{l}\text { Treatment-refractory to } \\
\text { all standard therapies }\end{array}$ & $\begin{array}{l}\text { Pembrolizumab } \\
200 \text { mg every } \\
3 \text { weeks }\end{array}$ & & ORR $39.6 \%$ & $\begin{array}{l}47- \\
53\end{array}$ \\
\hline $\begin{array}{l}\text { KEYNOTE-059 (phase II)/ } \\
\text { pembrolizumab }\end{array}$ & $\begin{array}{l}\text { Advanced gastric } \\
\text { or gastroesophageal } \\
\text { junction cancer } \\
(n=259)\end{array}$ & $\begin{array}{l}\text { PD-L } 1 \geq 1 \% \text { and } \\
\text { progression on } \geq 2 \\
\text { lines of chemotherapy }\end{array}$ & $\begin{array}{l}\text { Pembrolizumab } \\
200 \text { mg every } \\
3 \text { weeks }\end{array}$ & & ORR 11.2\% (95\% Cl 7.6-15.7) & 54 \\
\hline $\begin{array}{l}\text { CheckMate } 142 \\
\text { (phase II)/ } \\
\text { nivolumab }\end{array}$ & $\begin{array}{l}\text { Metastatic colorectal } \\
\text { cancer }(n=74)\end{array}$ & $\begin{array}{l}\text { Previously treated with } \\
\text { fluoropyrimidine, } \\
\text { oxaliplatin, and irinotecan }\end{array}$ & $\begin{array}{l}\text { Nivolumab } \\
3 \mathrm{mg} / \mathrm{kg} \text { every } \\
2 \text { weeks }\end{array}$ & & ORR 31.1\% (95\% Cl 20.8-42.9) & 55 \\
\hline $\begin{array}{l}\text { CheckMate } 040 \\
\text { (phase } 1 / 2 \text { ) }\end{array}$ & $\begin{array}{l}\text { Advanced } \\
\text { hepatocellular } \\
\text { carcinoma }(n=262)\end{array}$ & $\begin{array}{l}\text { Refractory to one } \\
\text { previous line of therapy } \\
\text { (including sorafenib), or } \\
\text { intolerant of sorafenib }\end{array}$ & $\begin{array}{l}\text { Nivolumab } \\
3 \mathrm{mg} / \mathrm{kg} \text { every } \\
2 \text { weeks }\end{array}$ & & $\begin{array}{l}\text { Safety 12/48 patients ( } 25 \%) \\
\text { grade 3-4 AEs with } 3(6 \%) \\
\text { having treatment-related } \\
\text { serious AEs (pemphigoid, } \\
\text { adrenal insufficiency, } \\
\text { liver disorder) } \\
\text { ORR 20\% ( } 95 \% \text { Cl 15-26\%) }\end{array}$ & 56 \\
\hline $\begin{array}{l}\text { JAVELIN Merkel } 200 \\
\text { (phase II) }\end{array}$ & $\begin{array}{l}\text { Merkel cell } \\
\text { carcinoma }(n=88)\end{array}$ & First-line and beyond & $\begin{array}{l}\text { Avelumab } \\
10 \mathrm{mg} / \mathrm{kg} \text { every } \\
2 \text { weeks }\end{array}$ & & $\begin{array}{l}\text { ORR } 31.8 \%(95.9 \% \\
\text { Cl 21.9-43.1) }\end{array}$ & 57 \\
\hline
\end{tabular}

FDA Food and Drug Administration, PD-1 programmed cell death 1, PD-L1 programmed death ligand 1, HNSCC head and neck squamous cell carcinoma, AEs adverse events, ORR overall response rate, $C l$ confidence interval, ICC investigator-choice chemotherapy, OS overall survival, HR hazard ratio, $C H L$ classical Hodgkin lymphoma, $C R$ complete response, ASCT autologous stem cell transplantation, MSI-H microsatellite instability-high, $d M M R$ defective mismatch repair

in 5 patients including myelodysplastic syndrome, pancreatitis, and pneumonitis. Results of this trial showed promising efficacy of nivolumab in cHL.

The CheckMate 205 trial was a phase II study enrolling 80 patients with cHL who had relapsed after ASCT or BV to receive nivolumab $3 \mathrm{mg} / \mathrm{kg}$ every 2 weeks [46]. The primary endpoint was independently assessed ORR and was $66.3 \%$ (53/80 patients) with 52 of the 53 responders having $>50 \%$ tumor reduction. Notably, in a post-hoc analysis of patients who did not have response to $\mathrm{BV}$ as the most recent treatment prior to trial recruitment, 31 of $43 \mathrm{pa}$ tients achieved objective response after nivolumab treatment. Grade $\geq 3 \mathrm{AEs}$ were seen in $25 \%$, the most frequent of which were increased lipase and neutropenia.

\section{Microsatellite instability or mismatch repair deficient cancers \\ Pembrolizumab}

In the first tissue-agnostic indication for a therapeutic agent, pembrolizumab was approved on May 23, 2017 
(Table 5) for patients with treatment-refractory unresectable or metastatic solid tumors that are microsatellite instability-high (MSI-H) or mismatch repair deficient (dMMR) [47-53]. Two phase 2 studies have showed ORR of $48 \%$ in 29 patients and $50 \%$ in 10 patients with various $\mathrm{dMMR}$ cancers, while a pivotal phase 2 study identified an ORR of $40 \%$ in 10 dMMR colorectal cancer (CRC) patients and an ORR of $71 \%$ in $7 \mathrm{dMMR}$ nonCRC patients $[48,52,53]$. As part of the ongoing, global, multicenter phase II studies KEYNOTE-164 and KEYNOTE-158, the ORR was $26.2 \%$ for $61 \mathrm{MSI}-\mathrm{H}$ CRC patients and $42.9 \%$ for 21 MSI-H non-CRC patients [47]. In 2 trials evaluating the role pembrolizumab in dMMR tumors, ORR was $50 \%$ in 28 dMMR CRC patients and $53 \%$ in 78 patients with various dMMR tumors [50, 51]. Another single-institution phase II study reported an ORR of $56 \%$ in 9 patients with dMMR endometrial cancer [49].

\section{Gastric cancer}

\section{Pembrolizumab}

Recently on September 22, 2017, pembrolizumab $200 \mathrm{mg}$ every 3 weeks was approved for advanced gastroesophageal cancer that is $\mathrm{PD}-\mathrm{L} 1 \geq 1 \%$ (IHC 22C3 antibody) and refractory $\geq 2$ lines of chemotherapy based on the phase II KEYNOTE-059 trial [54]. Out of 259 patients, the ORR was $11.2 \%$ (95\% CI 7.6-15.7) with a median duration of response of 8.1 months (Table 5). Grade 3-5 treatment-related AEs occurred in 43 patients (16.6\%) leading to discontinuation in 2 patients and death in 2 patients due to renal failure and pleural effusion.

\section{Colorectal cancer Nivolumab}

On August 1, 2017, nivolumab was approved in dMMR/ MSI-H metastatic colorectal cancer (mCRC) refractory to fluoropyrimidine, oxaliplatin, and irinotecan [55]. This approval was granted based on results from the CheckMate 142 trial, a phase II trial in which patients received nivolumab $3 \mathrm{mg} / \mathrm{kg}$ every 2 weeks and were stratified by PD-L $1<1 \%$ and PD-L1 $\geq 1 \%$. The primary endpoint was ORR per RECIST 1.1. Of the 74 patients enrolled, 23 patients (31\%) achieved ORR irrespective of PD-L1 levels (Table 5). Nivolumab-related grade $\geq 3$ AEs occurred in $12 \%$ of patients, most commonly fatigue, diarrhea, and pruritus.

\section{Hepatocellular carcinoma Nivolumab}

Recently on September 22, 2017, nivolumab $3 \mathrm{mg} / \mathrm{kg}$ every 2 weeks was approved in advanced hepatocellular carcinoma (HCC) refractory to sorafenib in the phase I/ II CheckMate 040 trial [56]. Of 262 eligible patients,
ORR was $20 \%$ (95\% CI 15-26\%) with no maximumtolerated dose established in the dose-escalation phase. Activity and tolerability did not appear to be affected by PD-L1 status or presence or absence of viral hepatitis (Table 5). Twelve of 48 patients (25\%) experienced grade 3-4 AEs with 3 patients (6\%) having treatment-related serious AEs (pemphigoid, adrenal insufficiency, liver disorder).

\section{Merkel cell carcinoma \\ Avelumab}

Avelumab, a fully humanized monoclonal IgG1 antibody against PD-L1, was first approved on March 23, 2017 for treatment of metastatic Merkel cell carcinoma (untreated and chemotherapy-resistant). This approval was granted based on the results of the JAVELIN trial, a single-arm phase II trial in which patients with stage 4 Merkel cell carcinoma refractory to $\geq 1$ previous line of chemotherapy received IV avelumab $10 \mathrm{mg} / \mathrm{kg}$ every 2 weeks [57]. The primary endpoint was ORR (Table 5). Complete response was observed in $9 \%$ of patients and partial response observed in $23 \%$, at a median follow-up time of 10.4 months. Among the patients whose tumors were assessable for PD-L1 expression (with PD-L1 positivity defined as a threshold level of $1 \%$ positive cells of any intensity), 34.5\% (95\% CI, 22.5-48.1) achieved objective responses. Grade $\geq 3$ toxicities were reported in $5 \%$ of patients including lymphopenia and isolated laboratory abnormalities.

\section{Discussion}

Since the FDA approvals of the first PD-1 inhibitors pembrolizumab and nivolumab in 2014, the clinical development of PD-1 and PD-L1 inhibitors as anticancer agents has picked up considerable momentum [13-15, $18]$. There are currently 5 PD-1/PD-L1 inhibitors that are FDA-approved in the treatment of a number of solid tumors (Tables 1, 2, 3, 4 and 5). Approved indications in this class of immune checkpoint inhibitors have also expanded to include hematologic malignancies and specific molecular phenotypes irrespective of solid tumor histology (i.e., tissue-agnostic) [45-53, 55]. As the number of PD-1/PD-L1 inhibitors undergoing development is expected to rise in the foreseeable future, several important points of discussion need to be considered in order to optimize the anticancer potential of this class of agents.

\section{Predictive biomarkers}

Despite the promising anticancer activity offered by PD1 and PD-L1 inhibitors, predicting tumor responses to PD-1/PD-L1 blockade remains a challenge given that not all patients derive benefit from this class of immunotherapy. Perhaps the earliest and most widely recognized 
predictive biomarker of response to $\mathrm{PD}-1 / \mathrm{PD}-\mathrm{L} 1$ blockade is PD-L1 expression, for which there are 4 FDAapproved assays of PD-L1 expression by IHC (Table 1) to help guide treatment decisions for nivolumab in advanced NSCLC or melanoma (Dako 28-8), pembrolizumab in advanced NSCLC (Dako 22C3), atezolizumab in advanced urothelial carcinoma or NSCLC (Ventana SP142), and durvalumab in advanced urothelial carcinoma (Ventana SP263) [20, 24, 27, 28, 35, 37, 38]. A recent meta-analysis involving 41 clinical trials and 6664 patients with advanced solid tumors investigated the predictive value of tumor and tumor-infiltrating immune cell PD-L1 expression by IHC assays such as Dako 28-8, Dako 22C3, Ventana SP142, Ventana SP263, and Dako clone 73-10 and demonstrated that PD-L1 expression was predictive of tumor response across all tumor types (odds ratio (OR) 2.26, 95\% confidence interval (CI) 1.85$2.75, p<0.001)$ [58]. Of note, the largest effect reaching significance was observed in NSCLC (OR 2.51, 95\% CI 1.99-3.17, $\mathrm{p}<0.001)$. However, despite the promising utility of PD-L1 expression as a biomarker for PD-1/PDL1 blockade, there is growing concern regarding its true predictability for response given its highly variable, heterogeneous, and dynamic expression on tumor or tumor-infiltrating immune cells [12]. Furthermore, technical differences and variation in screening thresholds for PD-L1 expression across assays represent additional limitations. This was shown in a recent multiinstitutional collaborative effort to provide information on the analytic comparability of the 4 FDA-approved IHC assays of PD-L1 expression (22C3, 28-8, SP142, and SP263) [59]. Out of 39 NSCLC tumors stained, 3/4 assays showed a comparable percentage of PD-L1stained tumor cells while the SP142 assay showed fewer stained tumor cells overall. There was greater variability in immune cell staining than tumor cell staining across all 4 assays. Notably, in $14 / 38$ cases (37\%) a different PD-L1 classification would have been made depending on which IHC assay and scoring system was used. A larger Phase II effort is currently underway to validate these findings. Nevertheless, although PD-L1 expression is associated with a higher likelihood of response to PD1/PD-L1 blockade, it has yet to be proven as the definitive biomarker for efficacy and its absence certainly does not preclude response to PD-1/PD-L1 inhibitors.

The search for the ideal biomarker of response to PD1/PD-L1 blockade is undergoing active investigation. There is increasing evidence to support that high mutational load can predict benefit from immune checkpoint inhibitors across several tumor types due to the immunogenic nature of neoantigens generated from an increased burden of nonsynonymous mutations [60]. For example, MSI or dMMR tumors are predisposed to accumulation of frameshift mutations due to defective
DNA repair machinery and have shown significantly greater responses to PD-1 blockade compared to microsatellite stable (MSS) or mismatch repair-proficient tumors [47-53, 55]. Tumors harboring POLE mutations represent another phenotype with high tumor mutational burden that may predict response to PD-1 blockade $[60,61]$. Other investigations have focused on the presence of an immune-active TME. Here, a TME associated with higher densities of CD8 + tumor-infiltrating lymphocytes (TILs) with a Th1 phenotype and more clonal T-cell receptor (TCR) repertoire, higher levels of interferon (IFN), IFN- $\gamma$-inducible genes, and IFNstimulated chemokines such as CXCL9, CLCL10, and CXCL11, and high levels of immune checkpoints such as cytotoxic T-lymphocyte antigen 4 (CTLA-4), PD-L1/ PD-L2, PD-1, and indoleamine 2,3-dioxygenase (IDO) may predict benefit from anti-PD-1 and anti-PD-L1 therapy $[12,60,62]$. In contrast to the immunologically "hot" TME, "cold" or non-T-cell-inflamed tumors have been associated with activated $\mathrm{Wnt} / \beta$-catenin pathway signaling and PTEN deficiency $[60,62]$. Features that define an immunologically hot or T-cell-inflamed tumor are becoming increasingly complex with evidence to support a role for CD4+ T-cells, T-regulatory cells, and myeloid-derived suppressor cells in contributing to a TME that is responsive to PD-1/PD-L1 blockade [60, 62].

Lastly, genetic polymorphisms and composition of the gut microbiome may also shape an individual's potential to respond to immune checkpoint inhibitors, and prospective studies are underway to investigate these novel concepts [12, 60, 62]. Significant differences in baseline diversity and composition of the gut microbiome between responders and nonresponders to anti-PD-1 therapy in metastatic melanoma patients have been reported, with enrichment of the Ruminococcaceae family of the Clostridiales order in responders whereas the Prevotellaceae family of the Bacteroidales order was enriched in nonresponders [63]. Other studies in melanoma mice models have identified that commensal gut bacteria such as Bifidobacterium putatively enhance response to anti-PD-L1 therapy by modulating immune responses through T-cell regulatory pathways [64]. Conversely, antibiotics can affect $30 \%$ of gut microbiota, and retrospective analyses in advanced solid tumor patients treated with anti-PD-1/PD-L1 therapy showed that receipt of antibiotics prior to immunotherapy was a negative predictor of survival on multivariate analysis [65]. Future directions of investigation may seek to explore the utility of a comprehensive assessment that takes into account features of the TME and other immune parameters to produce a composite score predictive of benefit to PD-1/PD-L1 blockade; one such tool, the Immunoscore, has already been demonstrated 
as a strong prognostic indicator in CRC with potential to guide immunotherapy strategies [66].

\section{Mechanisms of resistance and hyperprogressors}

Blockade of the PD-1/PD-L1 axis results in antitumor activity due to its ability, in part, to inhibit interferon-induced adaptive immune resistance characterized by interferoninduced JAK-STAT signaling that results in activation of interferon regulatory factor 1 (IRF1) and expression of PDL1 and IDO that allow for cancer cell immune evasion [67]. Innate resistance to anti-PD-1 therapy has been characterized by upregulation of genes involved in the regulation of cell adhesion, extracellular matrix remodeling, mesenchymal transition, angiogenesis, and wound healing [68]. Acquired resistance to checkpoint blockade has been characterized by loss of sensitivity to IFN- $\gamma$ either through mutations or epigenetic silencing of mediators of the IFN- $\gamma / /$ JAK/STAT/IRF1 signaling pathway [67, 69]. In addition, one study was among the first to describe the existence of a subset of patients (9\%) experiencing hyperprogressive disease defined as RECIST progression at first evaluation characterized by $\mathrm{a} \geq 2$-fold increase in tumor growth rate in response to anti-PD-1/PD-L1 therapy [70]. This novel pattern of hyperprogression was associated with higher age and worse OS. In a separate study, tumors from 155 patients with advanced cancers treated with PD-1/PD-L1 inhibitors were evaluated by next-generation sequencing to evaluate potential genomic markers associated with hyperprogressive disease defined as time-to-treatment failure (TTF $<2$ months, $>50 \%$ increase in tumor burden compared to pre-immunotherapy imaging, and $>2$ fold increase in progression pace [71]. Hyperprogessors to single-agent PD-1/PD-L1 blockade were found to have $M D M 2$ family amplifications or EGFR aberrations that significantly correlated to a TTF $<2$ months on multivariate analysis.

Further understanding of mechanisms of resistance and identification of hyperprogressors are certainly warranted in large, prospective cohorts to optimize efficacy and minimize risk to PD-1/PD-L1 inhibitors. Moreover, given the complexities of immunoregulatory pathways and host and tumor heterogeneity, combination strategies incorporating PD-1/PD-L1 blockade with vaccines, radiation therapy, stimulators of T-cell activity through targeting of CD40/CD40L, OX40/OX40L, and 4-1BB (CD137), co-targeting of other immune checkpoints such as T-cell immunoglobulin mucin 3 (Tim-3), lymphocyte activation gene 3 protein (LAG3), IDO, and T-cell immunoglobulin and ITIM domain (TIGIT), adoptive T-cell therapy, epigenetic reprogramming drugs, chemotherapy, and targeted agents such as vascular endothelial growth factor (VEGF)-directed therapy are increasingly being employed in clinical trials to enhance sensitivity to immunotherapy [62].

\section{Immune-related adverse events}

Paramount to the safe and effective administration of anti-PD-1 and anti-PD-L1 therapy is our greater recognition and understanding of their potential immunerelated toxicities. A recent meta-analysis of 3450 patients receiving $\mathrm{PD}-1 / \mathrm{PD}-\mathrm{L} 1$ inhibitors demonstrated higher risk of all-grade rash, pruritus, hypothyroidism, hyperthyroidism, colitis, aminotransferase elevations, and pneumonitis but lower risk of all-grade AEs in general and lower risk of all-grade fatigue, sensory neuropathy, diarrhea, hematologic toxicities, anorexia, nausea, and constipation, and treatment discontinuation when compared to chemotherapy [72]. Nevertheless, immunerelated toxicities can often be nontrivial resulting in significant risks that outweigh potential benefits of PD-1/ PD-L1 inhibitors. For example, beginning July 2017, the FDA has placed clinical holds on several clinical trials investigating pembrolizumab-, nivolumab-, and durvalumab-containing regimens in various hematologic malignancies based on findings and safety concerns identified from the KEYNOTE-183 and KEYNOTE-185 studies [73-75]. A detailed description of specific immune-related AEs and their management is beyond the scope of this review and has been extensively reviewed elsewhere; however, there is growing evidence that reassuringly shows use of systemic immunosuppressants may not negatively impact outcomes derived from checkpoint blockade [76-80].

\section{Treatment duration, treatment beyond progression, and response after prior PD-1/PD-L1 blockade}

The optimal duration of treatment with PD-1/PD-L1 inhibitors remains undefined but is of increasing relevance given the potential for delayed responses and the uncommon but documented phenomenon of pseudoprogression with immune checkpoint inhibitors [81]. Many randomized clinical trials investigating anti-PD-1 therapy across several tumor types have allowed for treatment beyond first progression (TBP) provided that patients continued to exhibit investigator-assessed clinical benefit, stable performance status, and tolerance to therapy without substantial adverse effects [81]. Available post hoc subgroup analyses of these trials have demonstrated that $9-48 \%$ of patients received TBP $\geq 4$ or 6 weeks with anti-PD-1 therapy, and of these, $13-33 \%$ of patients experienced $>30 \%$ target lesion reduction after progression when compared to baseline imaging [8185]. Compared to non-TBP patients, TBP patients often showed improved PFS and OS though often with higher incidence of treatment-related AEs consistent with prolonged exposure to anti-PD-1 therapy. It remains unclear, however, whether patients who experienced additional benefit with TBP had contributing factors such as better prognostic features and likely more 
indolent disease to begin with and whether the small subset of the overall population of patients that benefit from TBP is worth the increased toxicity, increased cost, and risk of delaying alternative and more effective therapies in choosing this approach [81]. Furthermore, many randomized clinical trials have employed conventional RECIST criteria to assess the efficacy of PD-1 inhibitors [82-86]. The novel iRECIST criteria has recently been proposed to allow more consistent interpretation of response and progression to cancer immunotherapy [87]. For the question of response to PD-1/PD-L1 blockade after prior treatment with PD-1/PD-L1 inhibitors, evidence is limited but appears to support an unlikely response with subsequent treatment in this scenario; there are, however, numerous ongoing and pending prospective clinical trials involving PD-1/PD-L1 blockade that allow prior treatment with PD-1/PD-L1 inhibitors that may provide more information on this topic [88]. Future studies of ideally prospective design are warranted to address remaining questions on optimal duration, TBP vs. switching to agents of a different class on progression, and treatment to progression or best response followed by rechallenge with $\mathrm{PD}-1 / \mathrm{PD}-\mathrm{L} 1$ inhibitors.

\section{Clinical trial design}

Lastly, several confirmatory phase III trials KEYNOTE040, IMVigor211, and CheckMate 026 have failed to meet their primary endpoints of PFS or OS despite promising results in prior studies that in some instances resulted in earlier FDA approval [89-91]. Differences in patient selection and baseline characteristics, variation among biomarker assays and PD-L1 expression cut-off thresholds, sampling for PD-L1 expression on metastatic lesions vs. archival tissue biopsy, subsequent immunotherapy in the standard of care arms, and outperformance or overachievement of study assumptions by standard of care therapies have been among the many, but not all, potential explanations for these recent results [89, 90, 92, 93]. There is curiosity regarding the fate of FDA-labeled indications for specific PD-1/PD-L1 inhibitors that were earlier approved but dependent on confirmatory phase III trials. Nevertheless, these negative trials highlight the importance of all aspects of clinical trial design in evaluating the efficacy of immune checkpoint inhibitors and provide invaluable learning for subsequent confirmatory trials. Furthermore, others have proposed implementation of iRECIST criteria and incorporation of weighted-log rank tests into future study designs as considerations to improve our interpretability of success or failure with PD1/PD-L1 inhibitors [87, 94].

\section{Conclusions}

Since the FDA approvals of the first PD-1 inhibitors pembrolizumab and nivolumab in 2014, the clinical development of PD-1/PD-L1 inhibitors as a form of cancer immunotherapy has seen unprecedented growth. There are currently 5 PD-1/PD-L1 inhibitors that are approved for the treatment of a spectrum of cancers including hematologic malignancies. As the number of anti-PD-1 and anti-PD-L1 therapies is expected to rise in the foreseeable future, there are several key issues that remain and require further investigation in order to optimize the anticancer potential of this class of agents. Specifically, predictive biomarkers, mechanisms of resistance, immune-related toxicities, hyperprogressors, treatment duration and TBP, and clinical trial design represent areas in need of further consideration to optimize benefit and minimize risks from PD-1/PD-L1 blockade.

\section{Abbreviations}

AEs: Adverse events; ALT: Alanine aminotransferase; ASCT: Autologous stem cell transplantation; AST: Aspartate aminotransferase; AUC: Area under the curve; BV: Brentuximab vedotin; CHL: Classical Hodgkin lymphoma; Cl: Confidence interval; CPK: Creatine phosphokinase; CRC: Colorectal carcinoma; CTLA-4: Cytotoxic T-lymphocyte antigen 4; dMMR: Mismatch repair deficient; FDA: Food and drug administration; HCC: Hepatocellular carcinoma; HNSCC: Head and neck squamous cell carcinoma; HR: Hazard ratio; ICC: Investigator-choice chemotherapy; IDO: Indoleamine 2,3dioxygenase; IFN: Interferon; IHC: Immunohistochemistry; IRF1: Interferon regulatory factor 1; IV: Intravenous; LAG3: Lymphocyte activation gene 3 protein; MSI-H: Microsatellite instability-high; MSS: Microsatellite stable; NSCLC: Non-small cell lung cancer; ORR: Overall response rate; OS: Overall survival; PD-1: Programmed cell death 1; PD-L1: Programmed death-ligand 1; PFS: Progression-free survival; RCC: Renal cell carcinoma; TBP: Treatment beyond first progression; TCR: T-cell receptor; TIGIT: T-cell immunoglobulin and ITIM domain (TIGIT); TILs: Tumor-infiltrating lymphocytes; TKI: Tyrosine kinase inhibitor; TME: Tumor microenvironment; TPS: Tumor proportion score; TTF: Time-to-treatment failure; UC: Urothelial carcinoma; VEGF: Vascular endothelial growth factor

\section{Acknowledgments \\ The authors thank Clayton Holder for graphical design assistance.}

Funding

Not applicable

Availability of data and materials

Not applicable

Authors' contributions

$J G, A C$, and $S R$ - literature search and review, writing, graphical design, and editing; RS - conception and design and editing. All authors read and approved the final manuscript.

Ethics approval and consent to participate

Not applicable

Consent for publication

Not applicable

Competing interests

The authors declare that they have no competing interests.

\section{Publisher's Note}

Springer Nature remains neutral with regard to jurisdictional claims in published maps and institutional affiliations. 


\section{Author details}

Department of Medical Oncology, City of Hope National Medical Center, 1500 E Duarte St, Duarte, CA 91010, USA. ²Department of Internal Medicine, Harbor-UCLA Medical Center, 1000 W Carson St, Torrance, CA 90509, USA. ${ }^{3}$ Medical Oncology and Experimental Therapeutics, City of Hope Comprehensive Cancer Center, Building 51, Room 101, 1500 E Duarte St, Duarte, CA 91010, USA.

\section{Received: 22 October 2017 Accepted: 9 January 2018}

\section{Published online: 23 January 2018}

\section{References}

1. Agata $Y$, Kawasaki A, Nishimura H, Ishida $Y$, Tsubata $T$, Yagita H, et al. Expression of the PD-1 antigen on the surface of stimulated mouse $T$ and $B$ lymphocytes. Int Immunol. 1996:8:765-72.

2. Ishida Y, Agata Y, Shibahara K, Honjo T. Induced expression of PD-1, a novel member of the immunoglobulin gene superfamily, upon programmed cell death. EMBO J. 1992:11:3887-95.

3. Nishimura H, Nose M, Hiai H, Minato N, Honjo T. Development of lupus-like autoimmune diseases by disruption of the PD-1 gene encoding an ITIM motif-carrying immunoreceptor. Immunity. 1999;11:141-51.

4. Freeman GJ, Long AJ, Iwai Y, Bourque K, Chernova T, Nishimura $\mathrm{H}$, et al Engagement of the PD-1 immunoinhibitory receptor by a novel B7 family member leads to negative regulation of lymphocyte activation. J Exp Med. 2000;192:1027-34.

5. Dong H, Zhu G, Tamada K, Chen L. B7-H1, a third member of the B7 family, co-stimulates T-cell proliferation and interleukin-10 secretion. Nat Med. 1999;5:1365-9.

6. Greenwald RJ, Freeman GJ, Sharpe AH. The B7 family revisited. Annu Rev Immunol. 2005;23:515-48.

7. Dong H, Strome SE, Salomao DR, Tamura H, Hirano F, Flies DB, et al. Tumorassociated B7-H1 promotes T-cell apoptosis: a potential mechanism of immune evasion. Nat Med. 2002:8:793-800.

8. Iwai Y, Ishida M, Tanaka Y, Okazaki T, Honjo T, Minato N. Involvement of PD-L1 on tumor cells in the escape from host immune system and tumor immunotherapy by PD-L1 blockade. Proc Natl Acad Sci U S A. 2002;99:12293-7.

9. Patnaik A, Kang SP, Rasco D, Papadopoulos KP, Elassaiss-Schaap J, Beeram M, et al. Phase I study of pembrolizumab (MK-3475; anti-PD-1 monoclonal antibody) in patients with advanced solid tumors. Clin Cancer Res. 2015;21: 4286-93.

10. Brahmer JR, Tykodi SS, Chow LQ, Hwu WJ, Topalian SL, Hwu P, et al. Safety and activity of anti-PD-L1 antibody in patients with advanced cancer. N Engl J Med. 2012;366:2455-65.

11. Topalian SL, Hodi FS, Brahmer JR, Gettinger SN, Smith DC, McDermott DF, et al. Safety, activity, and immune correlates of anti-PD-1 antibody in cancer. N Engl J Med. 2012;366:2443-54.

12. Balar AV, Weber JS. PD-1 and PD-L1 antibodies in cancer: current status and future directions. Cancer Immunol Immunother. 2017;66:551-64.

13. Hamid O, Robert C, Daud A, Hodi FS, Hwu WJ, Kefford R, et al. Safety and tumor responses with lambrolizumab (anti-PD-1) in melanoma. N Engl J Med. 2013;369:134-44

14. Robert C, Ribas A, Wolchok JD, Hodi FS, Hamid O, Kefford R, et al. Antiprogrammed-death-receptor-1 treatment with pembrolizumab in ipilimumab-refractory advanced melanoma: a randomised dose-comparison cohort of a phase 1 trial. Lancet. 2014;384:1109-17.

15. Ribas A, Wolchok JD, Robert C, Kefford R, Hamid O, Daud A, et al. P0116 updated clinical efficacy of the anti-PD-1 monoclonal antibody pembrolizumab (MK-3475) in 411 patients with melanoma [abstract]. Eur J Cancer. 2015;51:Abstr nr P0116.

16. Robert C, Schachter J, Long GV, Arance A, Grob JJ, Mortier L, et al. Pembrolizumab versus ipilimumab in advanced melanoma. N Engl J Med. 2015;372:2521-32

17. Ribas A, Puzanov I, Dummer R, Schadendorf D, Hamid O, Robert C, et al. Pembrolizumab versus investigator-choice chemotherapy for ipilimumabrefractory melanoma (KEYNOTE-002): a randomised, controlled, phase 2 trial. Lancet Oncol. 2015;16:908-18.

18. Weber JS, D'Angelo SP, Minor D, Hodi FS, Gutzmer R, Neyns B, et al. Nivolumab versus chemotherapy in patients with advanced melanoma who progressed after anti-CTLA-4 treatment (CheckMate 037): a randomised, controlled, open-label, phase 3 trial. Lancet Oncol. 2015;16:375-84.
19. Postow MA, Chesney J, Pavlick AC, Robert C, Grossmann K, McDermott D, et al. Nivolumab and ipilimumab versus ipilimumab in untreated melanoma. N Engl J Med. 2015;372:2006-17.

20. Larkin J, Chiarion-Sileni V, Gonzalez R, Grob JJ, Cowey CL, Lao CD, et al. Combined nivolumab and ipilimumab or monotherapy in untreated melanoma. N Engl J Med. 2015;373:23-34.

21. Sul J, Blumenthal GM, Jiang X, He K, Keegan P, Pazdur R. FDA approval summary: Pembrolizumab for the treatment of patients with metastatic non-small cell lung cancer whose tumors express programmed deathligand 1 [abstract]. Oncologist. 2016;21:643-50.

22. Hui R, Gandhi L, Costa EC, Felip E, Ahn MJ, Eder JP, et al. Long-term OS for patients with advanced NSCLC enrolled in the KEYNOTE-001 study of pembrolizumab (pembro). J Clin Oncol. 2016;34:Abstr nr 9026.

23. Garon EB, Rizvi NA, Hui R, Leighl N, Balmanoukian AS, Eder JP, et al. Pembrolizumab for the treatment of non-small-cell lung cancer. N Engl J Med. 2015;372:2018-28.

24. Herbst RS, Baas P, Kim DW, Felip E, Pérez-Gracia JL, Han JY, et al. Pembrolizumab versus docetaxel for previously treated, PD-L1-positive, advanced non-small-cell lung cancer (KEYNOTE-010): a randomised controlled trial. Lancet. 2016:387:1540-50.

25. Reck M, Rodríguez-Abreu D, Robinson AG, Hui R, Csőszi T, Fülöp A, et al. Pembrolizumab versus chemotherapy for PD-L1-positive non-small-cell lung cancer. N Engl J Med. 2016;375:1823-33.

26. Langer CJ, Gadgeel SM, Borghaei H, Papadimitrakopoulou VA, Patnaik A Powell SF, et al. Carboplatin and pemetrexed with or without pembrolizumab for advanced, non-squamous non-small-cell lung cancer: a randomised, phase 2 cohort of the open-label KEYNOTE-021 study. Lancet Oncol. 2016;17:1497-508.

27. Brahmer J, Reckamp KL, Baas P, Crinò L, Eberhardt WE, Poddubskaya E, et al. Nivolumab versus docetaxel in advanced squamous-cell non-small-cell lung cancer. N Engl J Med. 2015;373:123-35.

28. Borghaei H, Paz-Ares L, Horn L, Spigel DR, Steins M, Ready NE, et al. Nivolumab versus docetaxel in advanced nonsquamous non-small-cell lung cancer. N Engl J Med. 2015;373:1627-39.

29. Fehrenbacher L, Spira A, Ballinger M, Kowanetz M, Vansteenkiste J, Mazieres J, et al. Atezolizumab versus docetaxel for patients with previously treated non-small-cell lung cancer (POPLAR): a multicentre, open-label, phase 2 randomised controlled trial. Lancet. 2016;387: 1837-46.

30. Rittmeyer A, Barlesi F, Waterkamp D, Park K, Ciardiello F, von Pawel J, et al. Atezolizumab versus docetaxel in patients with previously treated nonsmall-cell lung cancer (OAK): a phase 3, open-label, multicentre randomised controlled trial. Lancet. 2017:389:255-65.

31. Antonia SJ, Villegas A, Daniel D, Vicente D, Murakami S, Hui R, et al. Durvalumab after chemoradiotherapy in stage III non-small-cell lung cancer. N Engl J Med. 2017;377:1919-29.

32. Balar AV, Castellano D, O'Donnell PH, Grivas P, Vuky J, Powles T, et al. Firstline pembrolizumab in cisplatin-ineligible patients with locally advanced and unresectable or metastatic urothelial cancer (KEYNOTE-052): a multicentre, single-arm, phase 2 study. Lancet Oncol. 2017; https://doi.org/ 10.1016/S1470-2045(1017)30616-30612.

33. Bellmunt J, de Wit R, Vaughn DJ, Fradet $Y$, Lee $J$, Fong $L$, et al. Pembrolizumab as second-line therapy for advanced urothelial carcinoma. N Engl J Med. 2017;376:1015-26

34. Sharma P, Retz M, Siefker-Radtke A, Baron A, Necchi A, Bedke J, et al. Nivolumab in metastatic urothelial carcinoma after platinum therapy (CheckMate 275): a multicentre, single-arm, phase 2 trial. Lancet Oncol. 2017:18:312-22.

35. Rosenberg JE, Hoffman-Censits J, Powles T, van der Heijden MS, Balar AV, Necchi A, et al. Atezolizumab in patients with locally advanced and metastatic urothelial carcinoma who have progressed following treatment with platinum-based chemotherapy: a single-arm, multicentre, phase 2 trial. Lancet. 2016;387:1909-20.

36. Balar AV, Galsky MD, Rosenberg JE, Powles T, Petrylak DP, Bellmunt J, et al. Atezolizumab as first-line treatment in cisplatin-ineligible patients with locally advanced and metastatic urothelial carcinoma: a single-arm, multicentre, phase 2 trial. Lancet. 2017;389:67-76.

37. Massard C, Gordon MS, Sharma S, Rafii S, Wainberg ZA, Luke J, et al. Safety and efficacy of durvalumab (MED14736), an anti-programmed cell death ligand-1 immune checkpoint inhibitor, in patients with advanced urothelial bladder cancer. J Clin Oncol. 2016:34:3119-25. 
38. Hahn NM, Powles T, Massard C, Arkenau HT, Friedlander TW, Hoimes CJ, et al. Updated efficacy and tolerability of durvalumab in locally advanced or metastatic urothelial carcinoma (UC) [abstract]. J Clin Oncol. 2017;35:Abstr nr 4525.

39. Apolo AB, Infante JR, Balmanoukian A, Patel MR, Wang D, Kelly K, et al. Avelumab, an anti-programmed death-ligand 1 antibody, in patients with refractory metastatic urothelial carcinoma: results from a multicenter, phase Ib study. J Clin Oncol. 2017;35:2117-24.

40. Apolo AB, Ellerton JA, Infante JR, Agrawal M, Gordon MS, Aljumaily R, et al. Updated efficacy and safety of avelumab in metastatic urothelial carcinoma (mUC): pooled analysis from 2 cohorts of the phase $1 \mathrm{~b}$ Javelin solid tumor study [abstract]. J Clin Oncol. 2017;35:Abstr nr 4528.

41. Motzer RJ, Escudier B, McDermott DF, George S, Hammers HJ, Srinivas S, et al. Nivolumab versus everolimus in advanced renal-cell carcinoma. N Engl J Med. 2015;373:1803-13.

42. Seiwert TY, Burtness B, Mehra R, Weiss J, Berger R, Eder JP, et al. Safety and clinical activity of pembrolizumab for treatment of recurrent or metastatic squamous cell carcinoma of the head and neck (KEYNOTE-012): an open-label, multicentre, phase $1 \mathrm{~b}$ trial. Lancet Oncol. 2016;17:956-65.

43. Ferris RL, Blumenschein G, Fayette J, Guigay J, Colevas AD, Licitra L, et al. Nivolumab for recurrent squamous-cell carcinoma of the head and neck. N Engl J Med. 2016;375:1856-67.

44. Chen R, Zinzani PL, Fanale MA, Armand P, Johnson NA, Brice P, et al. Phase II study of the efficacy and safety of pembrolizumab for relapsed/refractory classic hodgkin lymphoma. J Clin Oncol. 2017;35:2125-32.

45. Ansell SM, Lesokhin AM, Borrello I, Halwani A, Scott EC, Gutierrez M, et al. PD-1 blockade with nivolumab in relapsed or refractory Hodgkin's lymphoma. N Engl J Med. 2015;372:311-9.

46. Younes A, Santoro A, Shipp M, Zinzani PL, Timmerman JM, Ansell S, et al. Nivolumab for classical Hodgkin's lymphoma after failure of both autologous stem-cell transplantation and brentuximab vedotin: a multicentre, multicohort, single-arm phase 2 trial. Lancet Oncol. 2016;17: 1283-94.

47. Diaz LA, Marabelle A, Delord JP, Shapira-Frommer R, Geva R, Peled N, et al. Pembrolizumab therapy for microsatellite instability high (MSI-H) colorectal cancer (CRC) and non-CRC [abstract]. J Clin Oncol. 2017;35:Abstr nr 3071.

48. Diaz LA, Uram JN, Wang H, Bartlett B, Kemberling H, Eyring A, et al. Programmed death-1 blockade in mismatch repair deficient cancer independent of tumor histology [abstract]. J Clin Oncol. 2016;34:Abstr nr 3003.

49. Fader AN, Diaz LA, Armstrong DK, Tanner EJ, Uram J, Eyring A, et al. Preliminary results of a phase II study: PD-1 blockade in mismatch repairdeficient, recurrent or persistent endometrial cancer. Gynecol Oncol. 2016; 141:206-7.

50. Le DT, Durham JN, Smith KN, Wang H, Bartlett BR, Aulakh LK, et al. Mismatch-repair deficiency predicts response of solid tumors to PD-1 blockade. Science. 2017; pii(eaan6733):https://doi.org/10.1126/science. aan6733.

51. Le DT, Uram JN, Wang H, Bartlett B, Kemberling $H$, Eyring A, et al. Programmed death-1 blockade in mismatch repair deficient colorectal cancer [abstract]. J Clin Oncol. 2016;34:Abstr nr 103.

52. Le DT, Uram JN, Wang $H$, Bartlett BR, Kemberling $H$, Eyring AD, et al. PD-1 blockade in tumors with mismatch-repair deficiency. N Engl J Med. 2015; 372:2509-20.

53. Le DT, Uram JN, Wang H, Kemberling $H$, Eyring A, Bartlett B, et al. PD-1 blockade in mismatch repair deficient non-colorectal gastrointestinal cancers [abstract]. J Clin Oncol. 2016;34:Abstr nr 195.

54. Fuchs CS, Doi T, Jang RW, Muro K, Satoh T, Machado M, et al. KEYNOTE-059 cohort 1: efficacy and safety of pembrolizumab (pembro) monotherapy in patients with previously treated advanced gastric cancer [abstract]. J Clin Oncol. 2017;35:Abstr nr 4003.

55. Overman MJ, McDermott R, Leach JL, Lonardi S, Lenz HJ, Morse MA, et al. Nivolumab in patients with metastatic DNA mismatch repair-deficient or microsatellite instability-high colorectal cancer (CheckMate 142): an openlabel, multicentre, phase 2 study. Lancet Oncol. 2017 https://doi.org/10. 1016/S1470-2045(1017)30422-30429.

56. El-Khoueiry AB, Sangro B, Yau T, Crocenzi TS, Kudo M, Hsu C, et al. Nivolumab in patients with advanced hepatocellular carcinoma (CheckMate 040): an open-label, non-comparative, phase 1/2 dose escalation and expansion trial. Lancet. 2017;389:2492-502.

57. Kaufman HL, Russell J, Hamid O, Bhatia S, Terheyden P, D'Angelo SP, et al. Avelumab in patients with chemotherapy-refractory metastatic Merkel cell carcinoma: a multicentre, single-group, open-label, phase 2 trial. Lancet Oncol. 2016:17:1374-85.

58. Khunger M, Hernandez AV, Pasupuleti V, Rakshit S, Pennell NA, Stevenson J, et al. Programmed cell death 1 (PD-1) ligand (PD-L1) expression in solid tumors as a predictive biomarker of benefit from PD-1/PD-L1 axis inhibitors: A systematic review and meta-analysis. JCO Precision Oncology. 2017 https://doi.org/10.1200/PO.1216.00030.

59. Hirsch FR, McElhinny A, Stanforth D, Ranger-Moore J, Jansson M, Kulangara $K$, et al. PD-L1 immunohistochemistry assays for lung cancer: results from phase 1 of the blueprint PD-L1 IHC assay comparison project. J Thorac Oncol. 2017;12:208-22

60. Dijkstra KK, Voabil P, Schumacher TN, Voest EE. Genomics- and transcriptomics-based patient selection for cancer treatment with immune checkpoint inhibitors: a review. JAMA Oncol. 2016;2:1490-5.

61. Gong J, Wang C, Lee PP, Chu P, Fakih M. Response to PD-1 blockade in microsatellite stable metastatic colorectal cancer harboring a POLE mutation. J Natl Compr Cancer Netw. 2017;15:142-7.

62. Zou W, Wolchok JD, Chen L. PD-L1 (B7-H1) and PD-1 pathway blockade for cancer therapy: mechanisms, response biomarkers, and combinations. Sci Transl Med. 2016;8:328rv324.

63. Gopalakrishnan V, Spencer C, Reuben A, Prieto P, Vicente D, Karpinets TV, et al. Response to anti-PD-1 based therapy in metastatic melanoma patients is associated with the diversity and composition of the gut microbiome [abstract]. Cancer Res. 2017;77:Abstr nr 2672.

64. Sivan A, Corrales L, Hubert N, Williams JB, Aquino-Michaels K, Earley ZM, et al. Commensal Bifidobacterium promotes antitumor immunity and facilitates anti-PD-L1 efficacy. Science. 2015;350:1084-9.

65. Saleh K, Khalife-Saleh N and Kourie HR. Is gut microbiome a predictive marker to response to immune checkpoint inhibitors? Immunotherapy. 2017; 9: https://doi.org/10.2217/imt-2017-0090.

66. Mlecnik B, Bindea G, Angell HK, Maby P, Angelova M, Tougeron D, et al. Integrative analyses of colorectal cancer show immunoscore is a stronger predictor of patient survival than microsatellite instability. Immunity. 2016; 44:698-711.

67. Abril-Rodriguez G, Ribas A. SnapShot: immune checkpoint inhibitors. Cancer Cell. 2017;31:848-848.e841.

68. Hugo W, Zaretsky JM, Sun L, Song C, Moreno BH, Hu-Lieskovan S, et al. Genomic and transcriptomic features of response to anti-PD-1 therapy in metastatic melanoma. Cell. 2016;165:35-44.

69. Zaretsky JM, Garcia-Diaz A, Shin DS, Escuin-Ordinas H, Hugo W, Hu-Lieskovan S, et al. Mutations associated with acquired resistance to PD-1 blockade in melanoma. N Engl J Med. 2016;375:819-29.

70. Champiat S, Dercle L, Ammari S, Massard C, Hollebecque A, Postel-Vinay S, et al. Hyperprogressive disease is a new pattern of progression in cancer patients treated by anti-PD-1/PD-L1. Clin Cancer Res. 2017;23:1920-8.

71. Kato S, Goodman A, Walavalkar V, Barkauskas DA, Sharabi A, Kurzrock R. Hyperprogressors after immunotherapy: analysis of genomic alterations associated with accelerated growth rate. Clin Cancer Res. 2017;23:4242-50.

72. Nishijima TF, Shachar SS, Nyrop KA, Muss HB. Safety and tolerability of PD-1/ PD-L1 inhibitors compared with chemotherapy in patients with advanced cancer: a meta-analysis. Oncologist. 2017;22:470-9.

73. AstraZeneca. Celgene and AstraZeneca provide update on the FUSION clinical trial programme. https:/www.astrazeneca.com/content/astraz/media-centre/ press-releases/2017/celgene-and-astrazeneca-provide-update-on-the-fusionclinical-trial-programme-07092017.html. Accessed 25 Sept 2017.

74. Bristol-Myers Squibb Press Release. Bristol-Myers Squibb provides an update on three Opdivo-based combination clinical studies in multiple myeloma. https:// news.bms.com/press-release/corporatefinancial-news/bristol-myers-squibbprovides-update-three-opdivo-based-combin. Accessed 25 Sept 2017.

75. U.S. Food and Drug Administration. FDA alerts healthcare professionals and oncology clinical investigators about two clinical trials on hold evaluating KEYTRUDA ${ }^{\otimes}$ (pembrolizumab) in patients with multiple myeloma. https://www.fda.gov/Drugs/DrugSafety/ucm574305.htm. Accessed 25 Sept 2017

76. Harmankaya K, Erasim C, Koelblinger C, Ibrahim R, Hoos A, Pehamberger H, et al. Continuous systemic corticosteroids do not affect the ongoing regression of metastatic melanoma for more than two years following ipilimumab therapy. Med Oncol. 2011;28:1140-4.

77. Horvat TZ, Adel NG, Dang TO, Momtaz P, Postow MA, Callahan MK, et al. Immune-related adverse events, need for systemic immunosuppression, and effects on survival and time to treatment failure in patients with melanoma 
treated with ipilimumab at memorial Sloan Kettering cancer center. J Clin Oncol. 2015;33:3193-8.

78. Weber JS, Hodi FS, Wolchok JD, Topalian SL, Schadendorf D, Larkin J, et al. Safety profile of nivolumab monotherapy: a pooled analysis of patients with advanced melanoma. J Clin Oncol. 2017;35:785-92.

79. Friedman CF, Proverbs-Singh TA, Postow MA. Treatment of the immunerelated adverse effects of immune checkpoint inhibitors: a review. JAMA Oncol. 2016;2:1346-53.

80. Haanen JBAG, Carbonnel F, Robert C, Kerr KM, Peters S, Larkin J, et al. Management of toxicities from immunotherapy: ESMO clinical practice guidelines for diagnosis, treatment and follow-up. Ann Oncol. 2017;28: iv119-42.

81. Blumenthal GM, Theoret MR and Pazdur R. Treatment beyond progression with immune checkpoint inhibitors-known unknowns. JAMA Oncol. 2017 https://doi.org/10.1001/jamaoncol.2017.

82. Escudier B, Motzer RJ, Sharma P, Wagstaff J, Plimack ER, Hammers HJ, et al. Treatment beyond progression in patients with advanced renal cell carcinoma treated with nivolumab in CheckMate 025. Eur Urol. 2017;72:368-76.

83. George S, Motzer RJ, Hammers HJ, Redman BG, Kuzel TM, Tykodi SS, et al. Safety and efficacy of nivolumab in patients with metastatic renal cell carcinoma treated beyond progression: a subgroup analysis of a randomized clinical trial. JAMA Oncol. 2016;2:1179-86.

84. Kazandjian D, Keegan P, Suzman DL, Pazdur R, Blumenthal GM. Characterization of outcomes in patients with metastatic non-small cell lung cancer treated with programmed cell death protein 1 inhibitors past RECIST version 1.1-defined disease progression in clinical trials. Semin Oncol. 2017:44:3-7.

85. Long GV, Weber JS, Larkin J, Atkinson V, Grob JJ, Schadendorf D, et al. Nivolumab for patients with advanced melanoma treated beyond progression: Analysis of 2 phase 3 clinical trials. JAMA Oncol. 2017 https:// doi.org/10.1001/jamaoncol.2017.1588

86. Eisenhauer EA, Therasse P, Bogaerts J, Schwartz LH, Sargent D, Ford R, et al. New response evaluation criteria in solid tumours: revised RECIST guideline (version 1.1). Eur J Cancer. 2009;45:228-47.

87. Seymour L, Bogaerts J, Perrone A, Ford R, Schwartz LH, Mandrekar S, et al. iRECIST: guidelines for response criteria for use in trials testing immunotherapeutics. Lancet Oncol. 2017:18:e143-52.

88. Martini DJ, Lalani AA, Bossé D, Steinharter JA, Harshman LC, Hodi FS, et al. Response to single agent PD-1 inhibitor after progression on previous PD-1/ PD-L1 inhibitors: a case series. J Immunother Cancer. 2017;5:66.

89. Carbone DP, Reck M, Paz-Ares L, Creelan B, Horn L, Steins M, et al. First-line nivolumab in stage IV or recurrent non-small-cell lung cancer. N Engl J Med. 2017;376:2415-26.

90. Cohen EE, Harrington KJ, Le Tourneau C, Dinis J, Licitra L, Ahn MJ, et al. Pembrolizumab (pembro) vs standard of care (SOC) for recurrent or metastatic head and neck squamous cell carcinoma (R/M HNSCC): phase 3 KEYNOTE-040 trial [abstract]. Ann Oncol. 2017;28:Abstr nr LBA45.

91. Roche. Roche provides update on phase III study of TECENTRIQ ${ }^{\oplus}$ (atezolizumab) in people with previously treated advanced bladder cancer. https:/www.roche.com/dam/jcr:8fa0d3ca-f68d-413c-a8fa-cb94514492e6/en/ med-cor-2017-05-10-e.pdf. Accessed 25 Sept 2017.

92. Duran I. Second-line treatment of urothelial cancer: Achievements and perspectives [oral presentation]. ESMO 2017 Congress. 2017: Madrid, Spain. 8 Sept 2017. https://cslide.ctimeetingtech.com/library/esmo/browse/search/ $2 \mathrm{dMo \# 2Hnb.}$

93. Remon J, Besse B, Soria JC. Successes and failures: what did we learn from recent first-line treatment immunotherapy trials in non-small cell lung cancer? BMC Med. 2017;15:55.

94. Su Z and Zhu M. Is it time for the weighted log-rank test to play a more important role in confirmatory trials? Contemp Clin Trials Comm. 2017 https://doi.org/10.1016/j.conctc.2017.1009.1007.

\section{Submit your next manuscript to BioMed Central and we will help you at every step:}

- We accept pre-submission inquiries

- Our selector tool helps you to find the most relevant journal

- We provide round the clock customer support

- Convenient online submission

- Thorough peer review

- Inclusion in PubMed and all major indexing services

- Maximum visibility for your research

Submit your manuscript at www.biomedcentral.com/submit
Biomed Central 